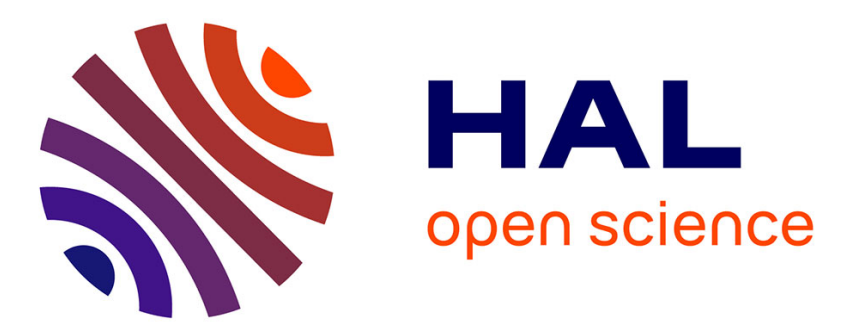

\title{
Decadal modelling of rainfall-runoff erosivity in the Euro-Mediterranean region using extreme precipitation indices
}

\author{
Nazzareno Diodato, Gianni G. Bellocchi
}

\section{- To cite this version:}

Nazzareno Diodato, Gianni G. Bellocchi. Decadal modelling of rainfall-runoff erosivity in the EuroMediterranean region using extreme precipitation indices. Global and Planetary Change, 2012, 86-87, pp.79-91. 10.1016/j.gloplacha.2012.02.002 . hal-02648222

\section{HAL Id: hal-02648222 \\ https://hal.inrae.fr/hal-02648222}

Submitted on 29 May 2020

HAL is a multi-disciplinary open access archive for the deposit and dissemination of scientific research documents, whether they are published or not. The documents may come from teaching and research institutions in France or abroad, or from public or private research centers.
L'archive ouverte pluridisciplinaire HAL, est destinée au dépôt et à la diffusion de documents scientifiques de niveau recherche, publiés ou non, émanant des établissements d'enseignement et de recherche français ou étrangers, des laboratoires publics ou privés. 


\title{
Decadal modelling of rainfall-runoff erosivity in the Euro-Mediterranean region using extreme precipitation indices
}

\author{
Nazzareno Diodato a , Gianni Bellocchi a,b,* \\ a Met European Research Observatory, HyMeX (GEWEX), World Climate Research Programme, Benevento, Italy \\ b Grassland Ecosystem Research Unit, French National Institute of Agricultural Research, 63100 Clermont-Ferrand, France
}

\section{A R T I C L E I N F O}

Article history:

Received 15 November 2011

Accepted 7 February 2012

Available online 16 February 2012

\section{Keywords:}

Central Europe and Mediterranean region (CEM)

Decadal Rainfall-Runoff Erosivity Multiscale Model (DREMM)

rainfall-runoff erosivity

Revised Universal Soil Loss Equation (RUSLE)

temporal variability

\begin{abstract}
A B S T R A C T
This paper presents and assesses the Decadal Rainfall Erosive Multiscale Model (DREMM), in which extreme precipitation data (95th percentile) are used to estimate decadal-scale rainfall-runoff erosivity values compatible with the Universal Soil Loss Equation and its revision - (R)USLE. The test area was a large region including central Europe and Mediterranean countries, in which 111 decades from 88 weather stations (ranging from about 3 to $1680 \mathrm{~m}$ above sea level) with rain and (R)USLE rainfall-runoff erosivity data were available. The construction of the model is simplified to a location-explicit term and to the understanding that the most erosive rainfalls are those recorded during the summertime and the beginning of autumn (May-October). These precipitation events are suitable for use in spatial and temporal climate variability studies on decadal time-scales. Once parameterized to capture decadal rainfall-runoff erosivity variability over central Europe and the Mediterranean, the DREMM was run to produce spatial patterns of rainfall-runoff erosivity in Germany and Bulgaria, compared to maps from the (R)USLE approach for 1961-1990. Implications for rainfall-runoff erosivity modelling were discussed concluding that a limited number of parameters may be sufficient to represent decadal rainfall-runoff erosivity for the central European and Mediterranean region. A transferable approach is recommended by employing the DREMM to assess the spatial impact of rainfall extremes. Its use to characterize the long-term dynamics of rainfall-runoff erosivity may also be of value in climate investigation.
\end{abstract}

(C) 2012 Elsevier B.V. All rights reserved.

\section{Introduction}

Intense and extreme rainstorms are a prominent environmental threat facing humankind, especially affecting the agricultural sector. In particular, seasonal distribution of rainfall erosivity indicates that storms-erosivity are much more severe during summer months (Wischmeier and Smith, 1978; Auerswald et al., 2009), while the component of runoff of the erosivity factor is more balanced or major in fall season, especially in late autumn (Foster et al., 1977; Hrissanthou, 2005). Rainstorms' interannual variability is thus an important part of the climate signal to detect potential changes in the power of rainfall and extreme precipitation, which are events of great importance for society (Sauerborn et al., 1999; Easterling et al., 2000; D'Odorico et al., 2001; Nearing et al., 2004; Schütt et al., 2007; Verheijen et al., 2009).

\footnotetext{
* Corresponding author at: Met European Research Observatory, HyMeX (GEWEX), World Climate Research Programme, Benevento, Italy. Tel./fax: + 39082461006.

E-mail addresses: scodalabdiodato@gmail.com (N. Diodato), giannibellocchi@yahoo.com (G. Bellocchi).
}

This is especially so for the Central Europe and Mediterranean regions, focus of this paper, where human pressure and erratic rainfall patterns with marked interannual variability expose landforms to exacerbated, damaging hydrological processes (Sánchez et al., 2004; van Rompaey et al., 2005), and also to spur the emergence of new hazards, such as coastal and urban flooding (Papathoma and Dominey-Howes, 2003; Barroca et al., 2006).

Apart from changes in the mean, changes in the variability and the frequency of extremes of climate variables are of great importance for the modelling purposes (Katz and Brown, 1992; Schär et al., 2004; Schaeffer et al., 2005). However, variations in extreme precipitations have been studied less intensely than changes in means or totals, especially at global and continental scales (Kenyon and Hegerl, 2010).

In the European and Mediterranean area, efforts have been made in the last decades to reconstruct hydrological regimes from alluvial sequences (Poesen and Hooke, 1997; Bintliff, 2002) and to report trends in extreme precipitation indices (Alpert et al., 2002; Lionello et al., 2006). Some of the most important advances are those by Gaume et al. (2009) and Llasat et al. (2010) concerning the European projects Hydrate (http://www.hydrate.tesaf.unipd.it) and FLASH (http://flash-eu. 
tau.ac.il), respectively. These projects approached, for the first time, the creation of a homogeneous catalogue of multiple damaging hydrological events across regions in Europe and Mediterranean. However, there is still a lack of summary indicators for characterization of extreme hydrological events over long periods.

In this study, we refer to the rainfall-runoff erosivity index of the Universal Soil Loss Equation (USLE, Wischmeier and Smith, 1978). Without setting any of the environmental thresholds (e.g. floods and landslides) generally used to support weather warnings and forecasting, the rainfall-runoff erosivity index can be considered a suitable climatic indicator of the impacts of rainstorms across European and Mediterranean lands, where extreme rainfalls are dominated by a wide range of rainy events types (e.g. Evrard et al., 2010). Relationships for rainfall-runoff erosivity estimation remain however difficult to be developed on homogeneous bases of data over broad areas where spatial-time variability of climatic variables is high. Also in areas where sufficiently and detailed long time series are available, the number of locations is generally insufficient to extrapolate with confidence rainfall-runoff erosivity patterns for both spatial and temporal scales (after Davison et al., 2005). For this, attempts have been made to assess rainfall-runoff erosivity at large spatial scales. At global scale, for instance, Yang et al. (2003) identified alternate power and simple polynomial relationships between annual values of rainfall-runoff erosivity and precipitation.

Diodato and Bellocchi (2010a) approached the regional scale for multidecadal estimation of rainfall-runoff erosivity over Mediterranean. The European and Mediterranen climate shows a complex pattern of spatial and annual variability, which is exacerbated by the intrinsic unpredictability of interannual rainfall-runoff erosivity from rainfall amount only (Diodato and Bellocchi, 2007, 2010a). Climatic events such as droughts and storms are sometimes clustered into longer-term groups. This means that their impacts may not vary simply in relation to their size, thus complicating any simple magnitude and frequency relationship (Diodato and Bellocchi, 2010b).

Climatic variability is recognized as one key cause of these clusterings. The global mean precipitation response to climate change can vary significantly on 20-year timescales both as a result of internal climate variability and changes in radiative forcing (Previdi and Liepert, 2008; Liepert and Previdi, 2009). The implication of this is that recently observed rainfall changes may be a poor indicator of changes that occur in hydro-climatological processes (after Previdi, 2010). Improving estimates of heavy precipitation with the use of the fractional contribution of very wet days to total precipitation from the probability distribution of daily rainfall, as in European Climate Assessment Project (Zolina et al., 2009) can be useful to elicit information involved in damaging extreme hydrological processes. However, it is difficult to establish the link between these rainfallindices and signals driving the rainfall-runoff erosivity over multidecadal spatio-temporal scales. A critical part of this link involves the evaluation of the spatio-temporal invariant of the model performance and scaling (Diodato and Bellocchi, 2009), with the difficulty in establishing whether a model is capable of correctly reproducing various statistics of the historical extreme rainfall climate signal (after Westra, 2011).

Rain rates and abstraction of extreme rainfalls over decadal scales could be a more suitable indicator to detect climatological forcing and to address hydrological patterns over both spatial and temporal scales. Following this idea, a novel rainfall-runoff erosivity model was developed and evaluated, linking the rainfall-runoff erosivity factor to readily available rainfall data to estimate decadal rates of rainfall-runoff erosivity (compatible with the USLE and its revision, RUSLE, by Renard et al., 1997) over the Euro-Mediterranean area.

The geographical representation chosen at a scale corresponding to central Europe and Mediterranean (intermediate on hemispheric and local scales) guarantees distinct properties of the subcontinental scale while preserving parsimoniousness of the rainfallrunoff erosivity model. In particular, the Decadal Rainfall Erosive Multiscale Model (DREMM) developed in this study incorporates few of relevant variables such as monthly precipitation and geographic data that are able to capture climatic variability at multiple spatial scales and are easily available nowadays via, for instance, web resources.

\section{Materials and methods}

\subsection{Study-area and data sources}

The Central Europe and Medieterranean study-area (referred to as CEM hereafter) extends over about $5,000,000 \mathrm{~km}^{2}$, centred across the Alps. The mapping of stations used (Fig. 1) roughly ranges from about $34^{\circ}$ (Ain Boukellal, Morocco) to $54^{\circ}$ (Suwalki, Poland) latitude north, and from about $8^{\circ}$ west (Rio Leça, Portugal) to $35^{\circ}$ east (Develi, Turkey) longitude. Elevations above sea level range from about $3 \mathrm{~m}$ of Pátrai (Greece) to $1680 \mathrm{~m}$ of La Molina (Spain), respectively. Annual rainfall-runoff erosivity values calculated with the (R)USLE - or with simplified methods of estimating the $R$-factor in (R)USLE - for different sites of central and Mediterranean Europe, North Africa and Middle East were derived from literature. In total, 111 data-points were available for this study, from 88 stations; multiple decades were available for six stations (Appendix A).

Within the global circulation system, central and Mediterranean Europe, North Africa and Middle East are located between the centres of action of the subtropical high pressure belt and the polar low pressure belt. Zonal and mixed circulations generally bring moist maritime airmasses from the tropic Atlantic into Europe, whereas meridional circulation can bring maritime polar airmasses or dry continental airmasses (polar or tropic source).

Numerous peaks and valleys characterize the CEM countries. This variegated morphology has important consequences on both sea and atmospheric circulations, which determine a non-uniform distribution of weather types (Lionello et al., 2006; James, 2007) and a large spectrum of hydrological events, found to vary considerably both over time and geographically (Macklin et al., 2006). A data analysis of extreme precipitation events in the CEM countries shows a distinct thermo-convection mode occurring in the afternoon over summer season (May-September), which takes about $3 \mathrm{~h}$ (van Delden, 2001; Twrdosz, 2007), and a cyclonic advection mode with precipitation duration of about $10 \mathrm{~h}$ (Kottmeier and Kunz, 2002; Twrdosz, 2007). Monthly rainfalls were derived from ECAD-European Climate Assessment \& Dataset (ECAD, http://eca.knmi.nl), and the Global Historical Climatology Networks (GHCN, http://www.ncdc.noaa.gov/ghcnm) via Climate Explorer (Van Oldenborgh et al., 2009).

\subsection{Multiscale model of rainfall-runoff erosivity}

Multiple linear and nonlinear regression models can be an option to account for spatial and temporal heterogeneity of a given variable. However, it may not be immediately clear what order of polynomial should be used, and a wrong expansion may hide important local variations in the model form (Charlton and Fotheringham, 2009).

Multi-level modelling is an alternative approach (after Goldstein, 1987), which combines models for individual and spatially aggregated characteristics within the same overall model. The underlying idea of a multiscale model is that parameters may be estimated anywhere in time and space given a dependent variable and a set of one or more independent variables, measured at places whose location is known. This same idea stems from the principle of Geographically Weighted Regression (e.g. Fotheringham et al., 2002), a version of spatial regression, which generates parameters disaggregated by spatial units 


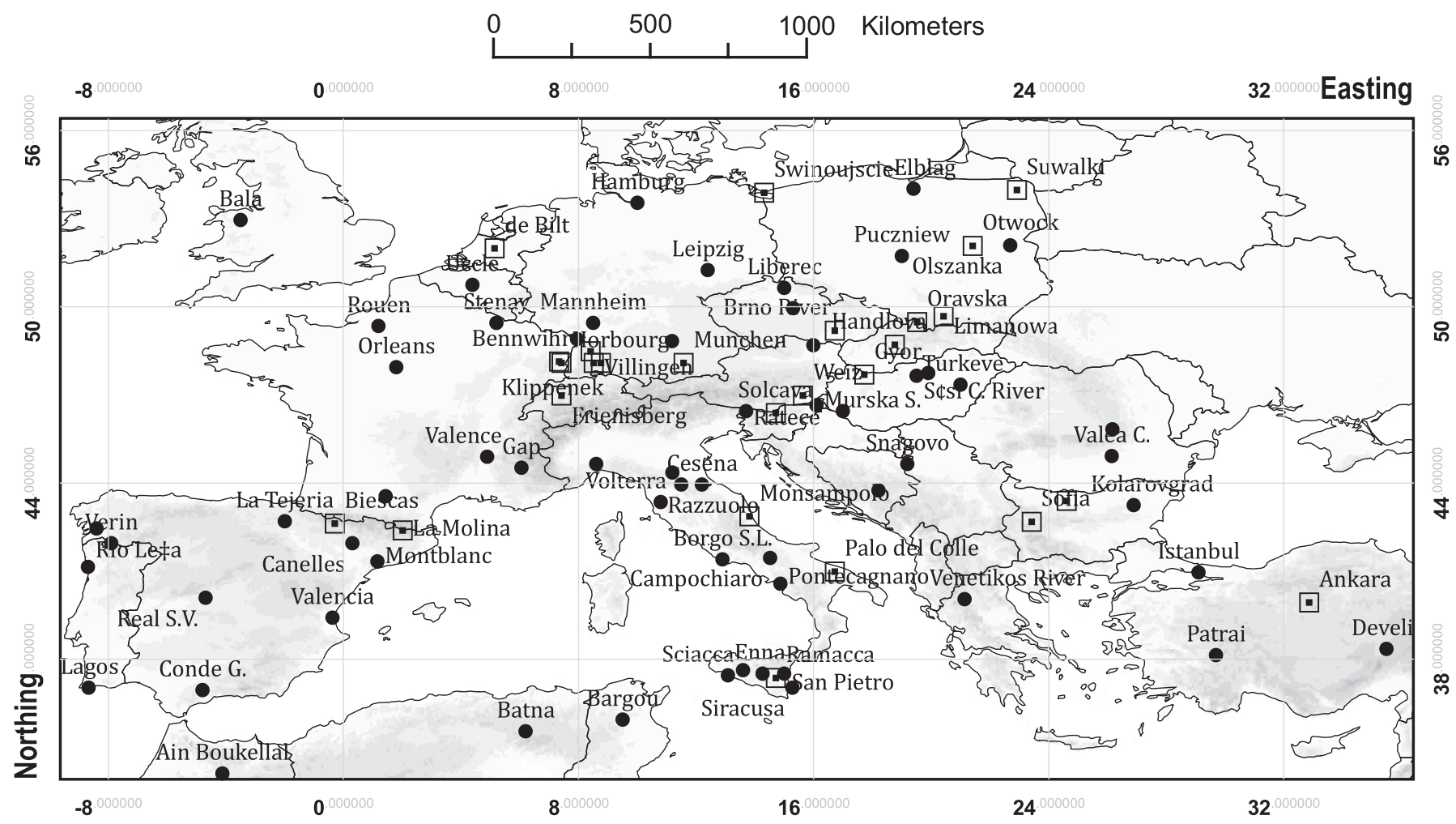

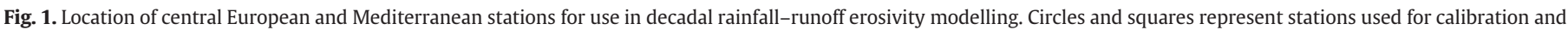
validation, respectively (as in Appendix A).

and whose typical expression is a linear combination of independent terms:

$y_{i}(\mathbf{u})=\beta_{0 i}(\mathbf{u})+\beta_{1 i}(\mathbf{u}) x_{1 i}+\beta_{2 i}(\mathbf{u}) x_{2 i}+\ldots+\beta_{m i}(\mathbf{u}) x_{m i}$

The notation $\beta_{0 i}(\mathbf{u})+\ldots+\beta_{m i}(\mathbf{u})$ indicates that each parameter $\beta$ describes a relationship around location $\mathbf{u}$ (vector $\mathbf{u}$ representing the coordinates of location) and is specific to that location. Prediction can be made for the dependent variable $\left(y_{i}\right)$ if measurements for the independent variables $\left(x_{i}\right)$ are also available at location $\mathbf{u}$.

To assess the amount of multi-year erosive events, series of monthly precipitation data may provide adequate time resolution for multiscale modelling purposes. Geographic elements were addressed in previous contributions (van der Knijff et al., 2000; Diodato and Bellocchi, 2007, 2010a) to estimate rainfall-runoff erosivity in the CEM zones.

In this study, the same principle was expanded to achieve a satisfactory solution in which monthly rainfall quantiles and the geographical control are modelled together to account for temporal and spatial dependence of rainfall-runoff erosivity. It is assumed that decadal mean annual rainfall-runoff erosivity values is a function of a quantile of the monthly precipitation distribution over the same decade, and that the parameters of this quantile vary with the raingauge location. Based on this understanding, summertime extreme rains are captured by percentile statistics across the months of May, June, July, August and September. Application of the general quantile regression technique has already yielded relationships between the rainfall-runoff erosivity factor and precipitation (e.g. Pelacani et al., 2008; Diodato et al., 2011).

The complex hydrological-erosivity system was deconstructed while preserving its representation for application-specific operability.
In particular, the conceptual model was resolved into a non-linear equation with parsimonious structure:

$R_{\text {DREMM }}=k \cdot\left(P_{\operatorname{prc} 95(M-S)}\right)^{\eta}+\alpha \cdot \sqrt{P_{(\max ) 0 c t}}$

where $R_{\mathrm{DREMM}}\left(\mathrm{MJ} \mathrm{mm} \mathrm{ha} \mathrm{a}^{-1} \mathrm{~h}^{-1} \mathrm{y}^{-1}\right.$ ) is the estimated decadal mean rainfall-runoff erosivity; $P_{\text {prc95(M-s) }}(\mathrm{mm})$ is the 95th percentile of the monthly rainfall from May $(\mathrm{M})$ to September $(\mathrm{S})$ over each decade; $P_{(\max ) \text { Oct }}(\mathrm{mm})$ is the maximum monthly rainfall in October over the decade; $k\left(\mathrm{MJ} \mathrm{mm}{ }^{\eta} \mathrm{ha}^{-1} \mathrm{~h}^{-1} \mathrm{y}^{-1}\right)$ and $\alpha\left(\mathrm{MJ} \mathrm{mm} \mathrm{m}^{0.5} \mathrm{ha}^{-1} \mathrm{~h}^{-1} \mathrm{y}^{-1}\right.$ ) is a scale parameter; $\eta$ is a shape term depending on the geographic location, in the following form:

$\eta=\beta+\gamma \cdot \mathrm{LAT}+\delta \cdot \mathrm{LONG}$

where $\beta$ is a shift parameter (a virtual value of $\eta$ at the point at which the equator and the prime meridian intersect), $\gamma\left({ }^{\circ-1}\right)$ and $\delta\left({ }^{\circ-1}\right)$ are scale parameters.

The parameters of Eqs. (2) and (3) were optimized by a co-iterative calibration process against mean decadal (R)USLE rainfall-runoff erosivity values. The best fit was obtained of a regression equation $Y=a+b \cdot X$, where $Y=$ model estimates and $X=$ actual data, according to the following criteria:

$\left\{\begin{array}{l}r^{2}=\max \\ N S=\max \\ |b-1|=\min \end{array}\right.$

First, the goodness-of-fit $\left(r^{2}\right.$, optimum $\left.=1\right)$ and the Nash-Sutcliffe $(N S$, optimum $=1)$ efficiency index (Nash and Sutcliffe, 1970) of the 
Table 1

Parameter values estimated from the entire dataset of stations and decades for the DREMM (Eq. (2)) and the exponent $\eta$ (Eq. (3)).

\begin{tabular}{lll}
\hline Parameter & DREMM & $\eta$ \\
\hline$\alpha\left(\mathrm{MJ} \mathrm{mm} \mathrm{m}^{0.5} \mathrm{ha}^{-1} \mathrm{~h}^{-1} \mathrm{y}^{-1}\right)$ & 24 & - \\
$\beta$ & - & 2.45950 \\
$\gamma\left({ }^{\circ-1}\right)$ & - & -0.02266 \\
$\delta\left(^{\circ-1}\right)$ & - & -0.00477 \\
\hline
\end{tabular}

linear function were maximized, and then the unit slope $(b)$ of the straight line that would minimize the bias was approximated. As additional measures, the intercept of the regression equation ( $a$, optimum $=0)$ and the mean absolute error $(M A E$, optimum $=0)$ were also calculated. The calibration process was performed over a subset of stations and decades, while 26 data (26 stations with one decade each, roughly $1 / 4$ of the total number of data) were held back randomly for validation (Appendix A). In order to provide proof of temporal-scale invariance, model performance was also shown for the six stations for which multiple decades were available (29 data).

The scale parameter $k$ to convert the first term of Eq. (2) - $P_{\mathrm{prc95}(\mathrm{M}-\mathrm{S})}^{\eta}-$ to $\mathrm{MJ} \mathrm{mm} \mathrm{ha}{ }^{-1} \mathrm{~h}^{-1} \mathrm{y}^{-1}$ was initially set equal to one and, for reasons of parsimony as given in Grace (2004), not treated as a free parameter because the initial value resulted in a fit that satisfied the criteria outlined by Eq. (4). The process was assessed interactively using Microsoft ${ }^{\circledR}$ Office Excel 2003 with the support of statistics software STATGRAPHIC Online (http://www.statgraphicsonline.com).

Parameter $\eta$ was also calibrated. Calibrated values of $\eta$ are those optimized against data once parameters $\beta, \gamma$ and $\delta$ of Eq. (2) are calibrated. In this case, 88 data were used for calibration, that is, only one decade per station was taken to ensure the same weight of each data-record (the median value was used for stations where multiple decades were available). Calibrated values of $\eta$ were compared against calculated values produced by Eq. (3).

A correlation analysis between terrain attributes and rainfall-runoff erosivity data was performed by geostatistical wizard in ArcGIS-ESRI, release 9.3 (Johnston, 2004). Terrain attributes are the environmental variables most commonly used with the hydrological data, since topography is an important forcing factor for erosive rainfall patterns. However, the evaluation of the effect of topography on precipitation is not straightforward. Elevation, in particular, is among the most relevant terrain variables controlling the precipitation pattern. The scales at which orographic effects are observed are critical for a region, with resolutions commonly varying between 1 and $3 \mathrm{~km}$ (Diodato, 2006).
In our case, Digital Elevation Model (DEM) with 1-km resolution was selected as an appropriate scale to account for terrain and station point features. The same ESRI-GIS tool was employed to create at random validation sites for the DREMM (grey cells in Appendix A).

\section{Results and discussion}

In this section, comparison between (R)USLE-based ('actual') and DREMM (modelled) rainfall-runoff erosivity data are presented and discussed. The assumptions behind the modelling solution of Eq. (2) are also discussed (nature of the variable exponent $\eta$, window of months for estimation of decadal rainfall-runoff erosivity, coevolution between erosivity and percentiles of rainfall, terrain characteristics). Rainfall-runoff erosivity patterns in nearby areas provided the basis for qualitative validation of the DREMM.

\subsection{Model parameterization and evaluation}

The optimized parameters of Eqs. (2) and (3) determined against (R)USLE rainfall-runoff erosivity data are given in Table 1.

Fig. 2a reports the calibration results for 85 data-points (as in Appendix A), where negligible departures of the data-points from the $1: 1$ line are observed. The model calibration was evaluated quantitatively based on the correlation and amount of residuals between the estimated and the actual data. The Nash-Sutcliffe (NS) efficiency index and the correlation coefficient $(r)$, equal to 0.92 and 0.95 (Table 2), are satisfactory. This is also due to the ability of Eq. (3) to capture the variability of the shape term $\eta$, as assessed by comparing modelled to calibrated results (Fig. $2 \mathrm{a}_{1}$; NS $=0.90, r=0.93$, Table 2). The estimated exponent values are greater than one, which means that a relatively small increase in the $P_{\text {prc95(M-S) }}$ values will produce a large change in decadal rainfall-runoff erosivity.

In order to assess the relevance of time scales, the performance of the DREMM was also examined by showing predicted against (R)USLE rainfall-runoff erosivity data for the stations where multiple decades were available (Fig. $2 \mathrm{~b} ; N S=0.83, r=0.92$, Table 2 ). The mean absolute error equal to $100 \mathrm{MJ} \mathrm{mm} \mathrm{ha}{ }^{-1} \mathrm{~h}^{-1} \mathrm{y}^{-1}$ is similar to that obtained over the calibration dataset $\left(M A E=111 \mathrm{MJ} \mathrm{mm} \mathrm{ha}{ }^{-1} \mathrm{~h}^{-1} \mathrm{y}^{-1}\right.$, Table 2), thus indicating some stability of the model in Eq. (2) on both spatial and temporal scales (scale invariance).

Independence-of-errors due to the possible presence of significant serial autocorrelations among the residuals was also tested. Strong temporal dependence may in fact induce spurious relations (see Granger et al., 2001). The Durbin-Watson statistic (Durbin and Watson, 1950, 1951), which tests the residuals to determine if there is any significant correlation based on the order in which they occur in the time series,
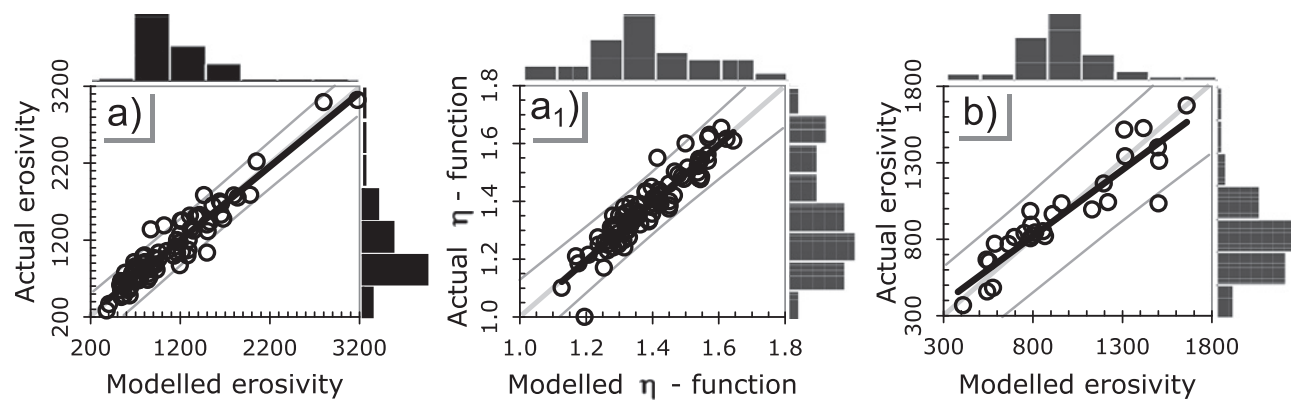

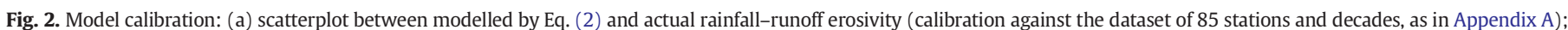

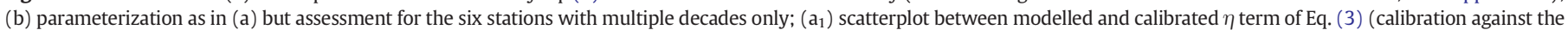

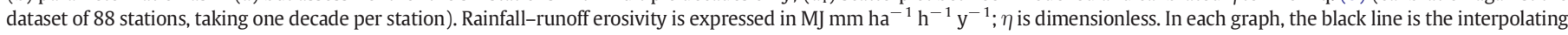
line, the bold grey line denotes the 1:1 line, and grey curves are 0.99 confidence limits of the interpolating line. Frequency distributions are reported on both axes. 
Table 2

Performance and autocorrelation statistics, calculated on alternative datasets for the DREMM (Eq. (2)) and the exponent $\eta$ (Eq. (3)).

\begin{tabular}{|c|c|c|c|c|c|c|c|}
\hline \multirow[t]{3}{*}{ Comparisons and datasets } & \multicolumn{5}{|c|}{ Performance statistics } & \multicolumn{2}{|c|}{ Autocorrelation statistics } \\
\hline & \multicolumn{2}{|c|}{ Least-squares regression } & \multirow{2}{*}{$\begin{array}{l}\text { Nash-Sutcliffe } \\
\text { efficiency } \\
\text { coefficient } \\
(N S)\end{array}$} & \multirow{2}{*}{$\begin{array}{l}\text { Correlation } \\
\text { coefficient } \\
(r)\end{array}$} & \multirow{2}{*}{$\begin{array}{l}\text { Mean absolute } \\
\text { error }(M A E)\end{array}$} & \multirow{2}{*}{$\begin{array}{l}\text { Lag-1 } \\
\text { residual } \\
\text { correlation }\end{array}$} & \multirow{2}{*}{$\begin{array}{l}\text { Durbin-Watson } \\
\text { statistic }\end{array}$} \\
\hline & $\begin{array}{l}\text { Intercept } \\
\text { (a) }\end{array}$ & $\begin{array}{l}\text { Slope } \\
(b)\end{array}$ & & & & & \\
\hline $\begin{array}{l}\text { 1. Modelled (Eq. (2)) versus (R)USLE rainfall-runoff } \\
\text { erosivity (calibration against the dataset of } 85 \\
\text { stations and decades, Appendix A) }\end{array}$ & 49 & 0.96 & 0.92 & 0.95 & $111^{\mathrm{a}}$ & 0.11 & $1.65(p=0.05)$ \\
\hline $\begin{array}{l}\text { 2. Modelled (Eq. (3)) versus calibrated } \eta \text { (dataset as } 1 \text {, } \\
\text { with one decade per station) }\end{array}$ & $-5.70 \mathrm{E}-03$ & 1.00 & 0.90 & 0.93 & $0.03^{b}$ & -0.02 & $2.03(p=0.52)$ \\
\hline $\begin{array}{l}\text { 3odelled (Eq. (2)) versus (R)USLE rainfall-runoff } \\
\text { erosivity (dataset of stations with multiple decades; } \\
\text { parameterization as in } 1 \text { ) }\end{array}$ & 127 & 0.87 & 0.83 & 0.92 & $100^{\mathrm{a}}$ & -0.32 & $2.61(p=0.94)$ \\
\hline $\begin{array}{l}\text { 4. Modelled (Eq. (2)) versus (R)USLE rainfall-runoff } \\
\text { erosivity (dataset with } 26 \text { stations, Appendix A; } \\
\text { parameterization as in } 1 \text { ) }\end{array}$ & -2.07 & 0.99 & 0.92 & 0.96 & $123^{\mathrm{a}}$ & -0.31 & $2.47(p=0.86)$ \\
\hline
\end{tabular}

indicates that serial autocorrelation in the residuals of the three equations are not significant $(p \geq 0.05)$.

Fig. 3 and Table 2 also show that the performance of the model (Eq. (2)) is still satisfactory when run against the independent set of 26 stations (as in Appendix A).

\subsection{Modelling assumptions: temporal and spatial patterns}

The assumptions that underly a model must be well understood and explicitly stated with reference to the conditions under which they are valid (Mulligan and Wainwright, 2004).

The DREMM in Eq. (2) represents rainfall-runoff erosivity through a power-law function involving a variable exponent. The scale parameter $\alpha$ is a conversion factor that can be conveniently assumed constant over time and space. The variable exponent is appealing because, not only does it provide a parsimonious description but, there is also a generic mechanism of the process. In general, geographic location is known to be an important input property to rainfall-runoff erosivity models because the location, and then the climate zone, accommodates a broad range of conditions related to the occurrence of abundant and intensive precipitations (e.g. Diodato and Bellocchi, 2010a). In Eq. (3), we assumed that the variable exponent may continuously vary with latitude and longitude (Fig. 4), as a shape term to modulate the percentile statistic that pulls out seasonal erosive rainfall between May and September (the warm season). Latitude appears to play a prominent role in the variability of $\eta$, with increasing values from northern latitudes (just above one) to more southern regions of Europe (up to about 1.8). Based on longitude, the magnitude of variability is much lower (up to about 20\%). This corresponds to the knowledge that high-intensity storms mainly affect areas from the subtropics to the lower temperate zones (e.g. Mariotti et al., 2005). It is also important to appreciate that the shape power-law exponent of Eq. (3) is a mechanism that serves to either attenuate or enhance rainfall--runoff erosivity depending on site-specific climate conditions. In the warm season, in fact, daily and sub-daily storms can be accompanied by high rain variability and intensity, thus releasing a large amount of energy through sparse phenomena, with rain-peaks generally concentrated in few hours (Diodato, 2004; Barrera et al., 2006; Twrdosz, 2007). This was also supported by the regime of within-year floods (Fig. 5b), including floods caused by heavy rains (flash floods).

An important issue at the stage of model development has been the choice of the window of months for estimation of decadal rainfall-runoff erosivity. In general, intense rainstorms fall between the end of spring and start of autumn. In the Northern hemisphere, the flood regimes that correspond to ice-jam floods over December-January, snowmelt floods in November and over March-April, and a mix of

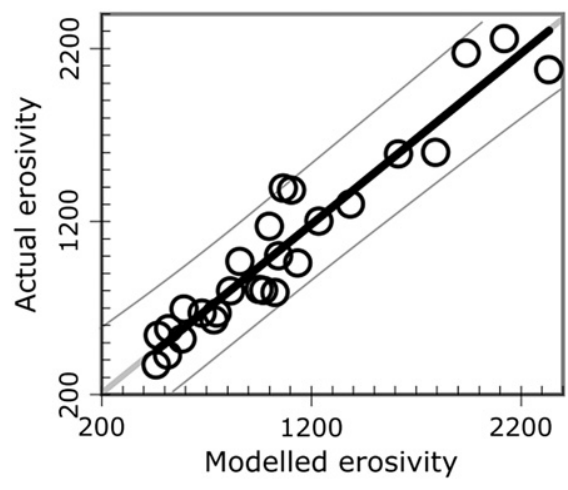

Fig. 3. Model validation: scatterplot between modelled by Eq. (2) and actual rainfallrunoff erosivity for the dataset of 26 stations as in Appendix A. The black line is the interpolating line, the bold grey line denotes the 1:1 line, and grey curves are 0.99 confidence limits of the interpolating line.

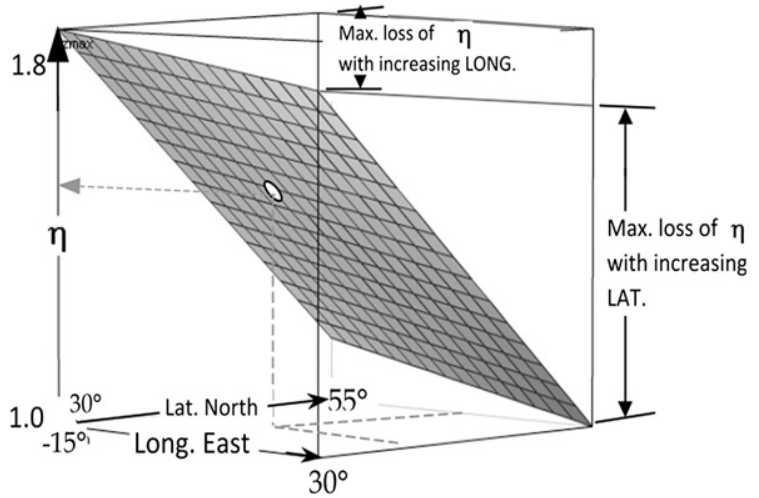

Fig. 4. Variation of the $\eta$ exponent (Eq. (3)) over the range of latitudes (LAT, ${ }^{\circ}$ ) and longitudes $\left(\right.$ LONG, ${ }^{\circ}$ ) covered by the study-area. 
a)

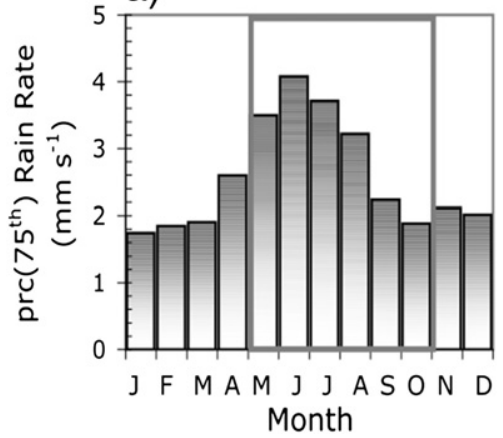

b)

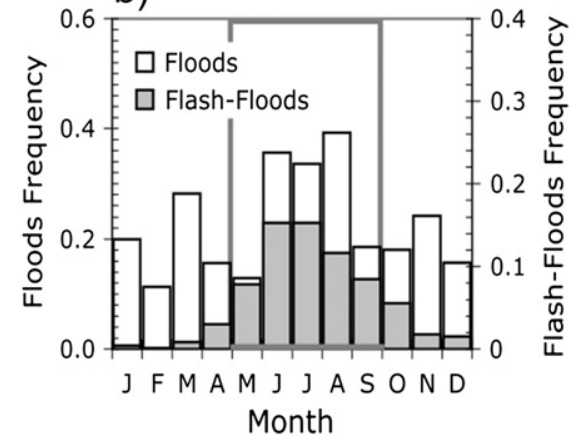

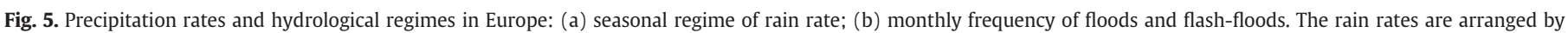

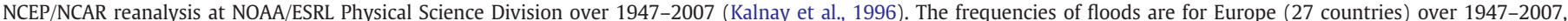

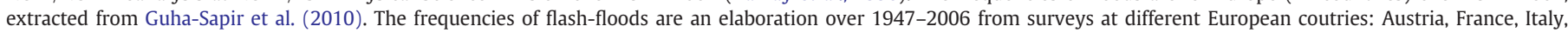

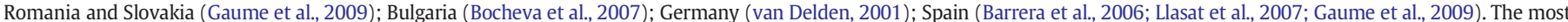

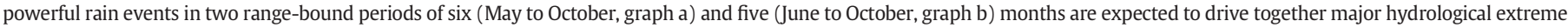
events and generate multiple damaging hydrological events.

both in February (Radziejewski, 2011) do not contribute to rainstorm erosivity. However, also in the warm season the climate varies greatly in different areas of the CEM region. This is why boundary months at either end of this period may be critical for rainfall-runoff erosivity modelling. It was observed, for instance, that the precipitations collected in May may not be an important driver of rainfall-runoff erosivity prediction in northern and eastern Europe, while they are useful inputs in western Europe and Mediterranean (data not shown). In the month of October, rain events present more homogeneous features most of the time, especially in western Europe (van Delden, 2001). Using the reanalysis data from ERA-40 (http://www.ecmwf.int/ research/era/do/get/era-40) for the period 1971-2000, Romero et al. (2007) described severe convective storms occurring between June and October in Europe. For Europe, the occurrence of severe thunderstorms is indeed intimately associated with the convective environmental conditions (Brooks et al., 2007). An analysis of precipitation rates and hydrological regimes also reveals that they are not uniform for different months (Fig. 5). The frequencies of flood and flash-flood events in Fig. 5b are from data-sparse basins in Europe. It is shown that the precipitation in May likely leads to a different regime of hydrological extremes compared to June-October, when flash-floods are more frequent (Fig. 5b).

This means that the period June-October delineates a key time window in estimating rainfall-runoff erosivity in Europe but, on the other hand, precipitations rate at the 75 th percentile (interpolated over Europe on $2.5^{\circ}$ latitude-longitude grid resolution) are more frequent in May than in late autumn (Fig. 5a). It is in this respect that we have taken October as a transition month. Its contribution to rainfall-runoff erosivity is less pronounced as the European continent may have rain rates less intense in this month than in prior months (Fig. 5a). Moreover, in the CEM region, the rains and storms become more extended and with longer duration with the continuing of the autumn season, thus exhibiting relevant geomorphological effectiveness towards more runoff-erosivity than the splash-erosive fraction (Diodato, 2006). This is why October rainfall was introduced as an additive component to the DREMM, i.e. $P_{(\max ) \text { Oct }}$ in Eq. (2), held out of the percentile calculation based on May to September precipitations. For October, the maximum precipitation amount over the decade $\left(P_{(\max ) \text { Oct }}\right)$ returns a non-linear effect (square root), directly converted into a rainfall-runoff erosivity fraction via the scale parameter $\alpha$. As we intend to show, satisfactory model performance can be obtained from some reasonable and physically sound assumptions (as illustrated above). Other modelling solutions were explored, essentially by changing the seasonal window over which the statistical percentile works. For instance, a simple solution was to calculate the 95th percentile during the window from May to September; another solution mirrored the final DREMM structure, but considering the window from June to October for the percentile calculation, and taking the square root of the May maximum precipitation as additive component. These and other avenues of model development were dropped because they performed well in some areas but not across the whole of the CEM. The model in Eq. (1) had the best fit, was the most parsimonious, and was consistent with the literature. However, the seasonal window over which the statistical percentile works remains a critical assumption and one that requires review in the future to ensure the reliability of DREMM estimates at sites where pluviometric series are missing (for punctual estimation, interpolation or validation purposes).

In an effort to provide rigor to the methodology, along with the ability to represent time-varying rainfall-runoff erosivity values, we compared extended summer (May-September) erosivity density ( $E D$, ratio between annual values of rainfall-runoff erosivity and rainfall total) to the 95th percentile ratio $(P R)$ between the same season and the remaining months (the value of rainfall below which $95 \%$ of the observed rain amounts fall over May-September divided by the same amount over the other months), calculated for Ukkel (Belgium), Naples (Italy) and Danube river basin (near Bratislava, Slovakia) for 1898-2006 (Fig. 6). From visual inspection, Fig. 6 shows that there is moderate co-evolution between $E D$ and $P R$ for both the towns of Ukkel, Belgium (graph a, correlation coefficient equal to 0.58 ) and Naples, Italy (graph b, correlation coefficient equal to 0.46), and for the Danube river basin (graph c, correlation coefficient equal to 0.86). This suggests that the DREMM (as developed and parameterized in this study) is sufficiently robust and may be liable to a spatial generalization for different climates, either dominated by Atlantic influences (Ukkel), continental regime (Danube river) or Mediterranean character (Naples).

Assumptions about representative terrain characteristics are regarded as playing a central role in hydroclimatology. Also, when these features are not explicitly included in the models, model outcomes and terrain co-variables should be comparable in the sense of having similar distribution. In our case, we have compared the elevation distribution of raingauge stations with the terrain elevation extracted from a digital elevation model (DEM) of $1-\mathrm{km}$ resolution. Fig. 7a shows that stations around hilly terrains (at about 400 to $800 \mathrm{~m}$ a.s.l.) tend to be more biased, compared to low- and high-altitude sites, 


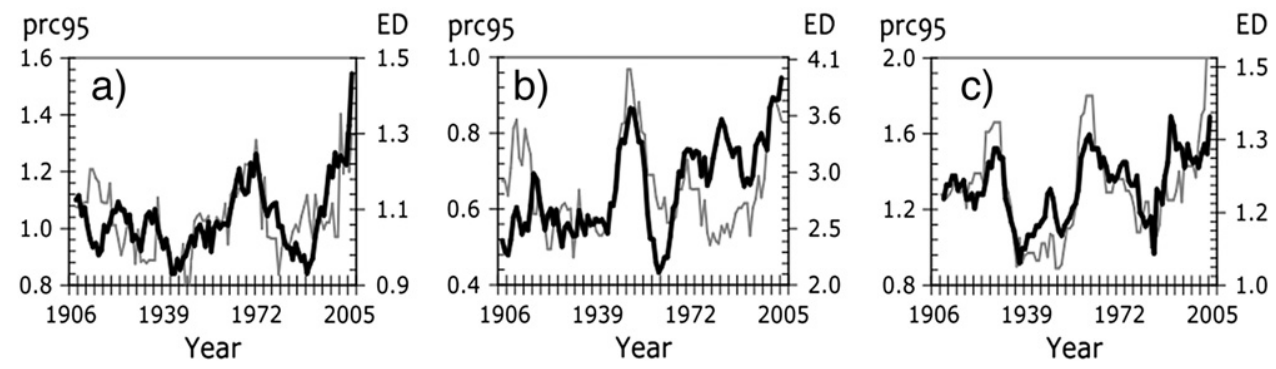

Fig. 6. Moving-window average on previous 10 years of annual erosivity density ( $E D$, grey curve), and 95th percentile ratio of monthly rainfall (PR) between the extended summer season (May-September) and the remaining months (bold curve) calculated at three European sites for 1898-2006: (a) Ukkel, Belgium; (b) Naples, Italy; (c) Danube river basin near Bratislava, Slovakia. Rainfall-runoff erosivity data were arranged from Chirico et al. (2010), Verstraeten et al. (2006) and Pekarova et al. (2008), respectively.

because the set of station data from mid-mountain locations is not entirely representative of the distribution of the DEM orography. In addition, in order to elucidate the relationships between the DREMM and terrain features, cross-covariance functions were examined for discovering sub-regional characteristics of spatial correlation between rainfall-runoff erosivity and elevation. Bit cells through which spatial shifts in correlation between stations altitude and both actual (Fig. $7 b_{1}$ ) and predicted (Fig. $7 b_{2}$ ) rainfall-runoff erosivity values are given. The cross-covariance surfaces reflect a similar pattern (although less pronounced with the DREMM), thus indicating that the DREMM may serve as a suitable model to generate spatial patterns of rainfallrunoff erosivity response consistent with the terrain complexity observed at the regional scale if the inter-station distance is less than $200 \mathrm{~km}$. For larger distances, the correlation between stations is not enough to be useful about the accuracy of patterns of response over large areas.

\subsection{Evaluation of spatial patterns}

We have applied the DREMM (parameterized against the dataset of 85 stations and decades as in Appendix A) to compare spatial patterns of rainfall-runoff erosivity (Fig. 8) and maps compatible with the (R)USLE approach for Germany (Hennings, 2003) and Bulgaria (Rousseva and Stefanova, 2006). Overall, the similar pattern generally observed between estimated and (R)USLE-calculated data suggests the possibility for the DREMM to be used for the construction of erosive maps at regional scale. Discrepancies between DREMM and (R)USLE data are indeed few and isolated. They may depend on the large scale on which the DREMM was developed with respect to the local scale used to compute the (R)USLE data. Moreover, some biases may have been introduced by the GPCC-V5 rainfall dataset, which includes smoothed gridded values and not the original data points.

\section{Conclusions}

Parsimonious hydro-climatological models hold potentials to simulate the combined effects of rainfall input patterns in the absence of precipitation records at short time intervals (e.g. daily to sub-hourly) and over large areas (e.g. regional to continental). The present study offers a parsimonious model of rainfall-runoff erosivity, the DREMM, which was evaluated and effectively used to assess the distribution of decadal mean rainfall-runoff erosivity over the CEM. It shows that the model holds potential to simulate decadal rainfall-runoff variability on sub-continental spatial scales. Its results need to be interpreted with caution to analyse erosivity in detail at the sub-regional versus local scales, where including a site-specific elevation term (with or without re-parameterization) could potentially improve the performance of the model (e.g. Meusburger et al., 2011). A different approach (e.g. Martí and Gasque, 2011) could be adding ancillary (local) pluviometric stations across the grid points (based on international datasets) in cases where the effect of elevation on rainfall-runoff erosivity is not reflected by a clear relationship. The limited number of stations used in this study also raises the need for refinement of the model and wider validation work. However, the satisfactory performance, which
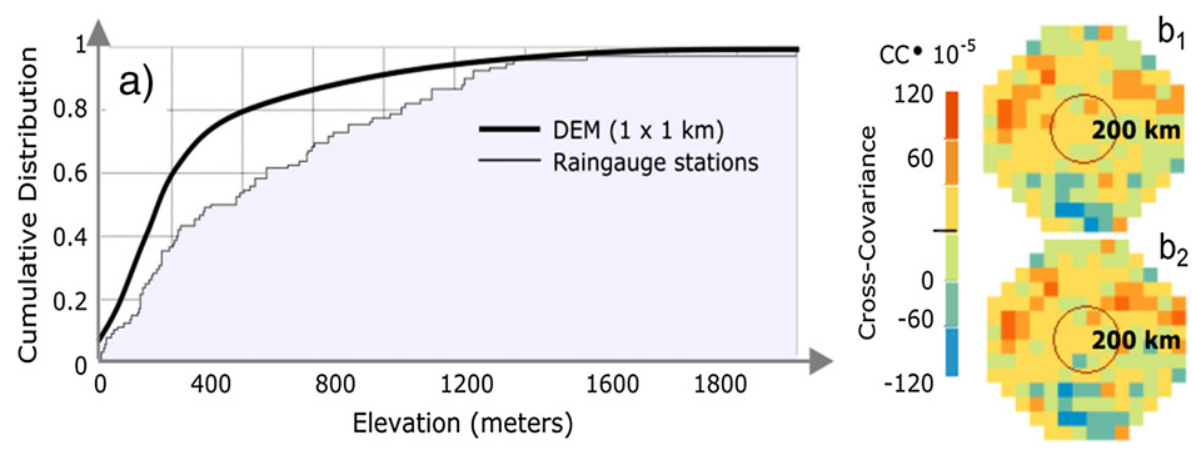

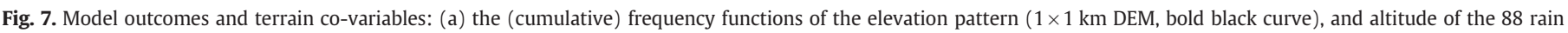

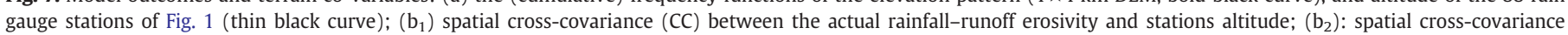

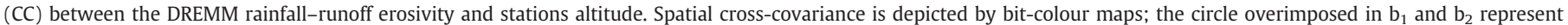

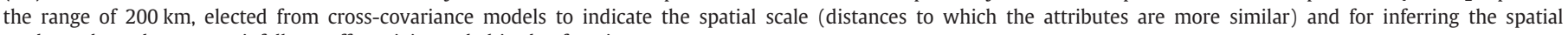
co-dependence between rainfall-runoff erosivity and altitude of stations. 


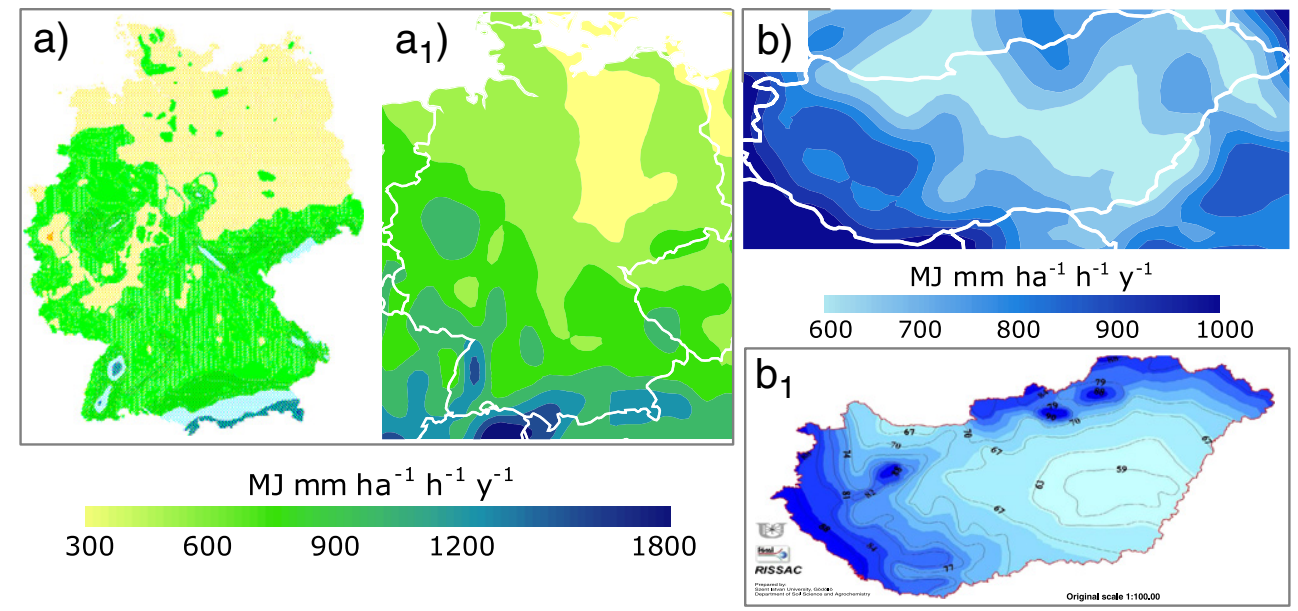

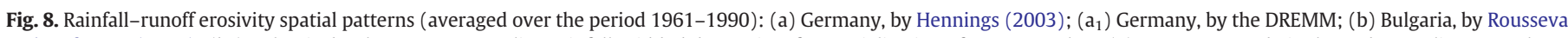

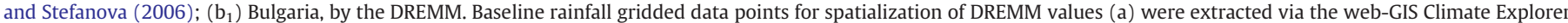

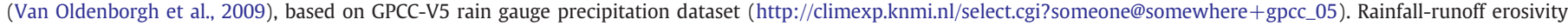
values in Fig. $8 \mathrm{~b}_{1}$ are in $10^{-1} \mathrm{MJ} \mathrm{mm} \mathrm{ha-1} \mathrm{h}^{-1} \mathrm{y}^{-1}$.

we have been able to achieve with the DREMM, is the result of sound assumptions and proper modelling of terms that constitute the essential of large-scale precipitation regime. In dealing with such a large and heterogeneous region, which includes stations from North Africa to the Atlantic-Baltic sector and from Iberian Peninsula to Middle East, there are constraints on the seasonal variability of extreme rainfalls that we can explain with just a small number of inputs. This confirms that regional-scale (sub-continental) modes of variability are important and extreme rainfall is not just controlled by local processes (Haylock and Goodess, 2004). Future work should focus on delineating the extents of these promising findings (e.g. at other portions of the Northern hemisphere) as well as clarifying the mechanisms for shaping broad-scale variations in extreme storms and rainfall erosivity. In addition, the DREMM approach lays the foundation for the reconstruction of historical hydroclimatic conditions, when detailed precipitation records are unavailable.

\section{Acknowledgements}

The above study is an investigator-driven study, run without grant support, developed in the frame of HyMeX-WG2 Hydrological Continental Cycle (http://mistrals.sedoo.fr/HyMeX/Plateform-search?datsId=532).

The authors acknowledge wide-ranging discussions with Lorenzo Borselli (Italian National Research Council, Research Institute for GeoHydrogeological Protection, Sesto Fiorentino, Italy) and Gert Verstraeten (Geography Research Group, K.U. Leuven, Belgium). They are also grateful to Matjaž Mikoš (Faculty of Civil and Geodetic Engineering, University of Ljubljana, Slovenia) for providing erosivity data series for Slovenia. 
Appendix A. Station sites, climate summaries, data availability. The total number of stations is 88 , six of which have multiple decades. Grey cells indicate 26 stations and decades used for validation of Eq. (2)

\begin{tabular}{|c|c|c|c|c|c|c|c|}
\hline Country & Station & $\begin{array}{l}\text { Latitude } \\
\text { (degree) }\end{array}$ & $\begin{array}{c}\text { Longitude } \\
\text { (degree) }\end{array}$ & $\begin{array}{c}\text { Elevation } \\
\text { (m) }\end{array}$ & $\begin{array}{l}\text { Actual rainfall- } \\
\text { runoff erosivity } \\
\left(\mathrm{MJ} \mathrm{mm} \mathrm{ha} \mathbf{~}^{-1} \mathbf{h}^{-1} \mathbf{y}^{-1}\right)\end{array}$ & $\begin{array}{l}\text { Period } \\
\text { (years) }\end{array}$ & Sources \\
\hline Algeria & Batna & 35.60 & 6.20 & 1000 & 813 & 1969-2001 & Khentouche (2005) \\
\hline \multirow[t]{2}{*}{ Austria } & Retz & 48.75 & 16.00 & 243 & 550 & 1971-1980 & Strauss et al. (1995) \\
\hline & Weiz & 47.00 & 15.63 & 480 & 1380 & 1976-1990 & Strauss et al. (1995) \\
\hline \multirow[t]{10}{*}{ Belgium } & Ukkel & 50.80 & 4.40 & 104 & 815 & 1898-1907 & Verstraeten et al. (2006) \\
\hline & Ukkel & 50.80 & 4.40 & 104 & 894 & 1908-1917 & Verstraeten et al. (2006) \\
\hline & Ukkel & 50.80 & 4.40 & 104 & 844 & 1918-1927 & Verstraeten et al. (2006) \\
\hline & Ukkel & 50.80 & 4.40 & 104 & 820 & 1928-1937 & Verstraeten et al. (2006) \\
\hline & Ukkel & 50.80 & 4.40 & 104 & 768 & 1938-1947 & Verstraeten et al. (2006) \\
\hline & Ukkel & 50.80 & 4.40 & 104 & 807 & 1948-1957 & Verstraeten et al. (2006) \\
\hline & Ukkel & 50.80 & 4.40 & 104 & 965 & 1958-1967 & Verstraeten et al. (2006) \\
\hline & Ukkel & 50.80 & 4.40 & 104 & 841 & 1968-1977 & Verstraeten et al. (2006) \\
\hline & Ukkel & 50.80 & 4.40 & 104 & 824 & 1978-1987 & Verstraeten et al. (2006) \\
\hline & Ukkel & 50.80 & 4.40 & 104 & 985 & 1988-1997 & Verstraeten et al. (2006) \\
\hline Bosnia-Erzegovina & Sarajevo & 43.80 & 18.20 & 511 & 1500 & $1953-1980$ & Arranged from Petković et al. (1999) \\
\hline \multirow[t]{3}{*}{ Bulgaria } & Kolarovgrad & 43.30 & 26.90 & 198 & 911 & 1960-1979 & Rousseva and Stefanova (2006) \\
\hline & Pleven & 43.40 & 24.60 & 75 & 1000 & 1960-1979 & Rousseva and Stefanova (2006) \\
\hline & Sofia & 42.70 & 23.40 & 550 & 1170 & 1960-1979 & Rousseva and Stefanova (2006) \\
\hline \multirow[t]{3}{*}{ Czech Republic } & Brno River & 49.20 & 16.70 & 360 & 520 & $1980-2000$ & Krasa et al. (2005) \\
\hline & Vrchlice Reservoir & 50.00 & 15.30 & 254 & 480 & 1971-2000 & Krasa et al. (2005) \\
\hline & Liberec & 50.70 & 15.00 & 374 & 760 & $1961-2000$ & Krasa et al. (2007) \\
\hline \multirow[t]{9}{*}{ France } & Bennwihr & 48.15 & 7.32 & 330 & 540 & 1966-1994 & Strauss et al. (1997) \\
\hline & Gap & 44.57 & 6.07 & 773 & 1650 & $1951-1970$ & Pihan (1978) \\
\hline & Horbourg-Wihr & 48.10 & 7.40 & 190 & 670 & 1968-1994 & Strauss et al. (1997) \\
\hline & Hunspach & 48.95 & 7.95 & 150 & 720 & 1976-1994 & Strauss et al. (1997) \\
\hline & Orleans & 48.00 & 1.80 & 125 & 680 & 1951-1970 & Pihan (1978) \\
\hline & Rouen & 49.40 & 1.20 & 879 & 879 & 1959-1988 & Arranged from Bollinne (1979) \\
\hline & Stenay & 49.50 & 5.20 & 180 & 1455 & 1950-2000 & Ward etal. (2009) \\
\hline & Tolouse & 43.60 & 1.44 & 187 & 1275 & 1951-1970 & Pihan (1978) \\
\hline & Valence & 44.95 & 4.90 & 106 & 1700 & 1951-1970 & Pihan (1978) \\
\hline \multirow[t]{12}{*}{ Germany } & Eichstrutt & 48.88 & 11.18 & 340 & 700 & 1961-1980 & Schweikle et al. (1985) \\
\hline & Freudenstadt & 48.50 & 8.40 & 728 & 1600 & $1961-1980$ & Schweikle et al.(1985) \\
\hline & Hamburg & 53.60 & 10.00 & 16 & 550 & $1961-1990$ & Wurbs and Steininger (2011) \\
\hline & Klippenek & 48.10 & 8.75 & 980 & 960 & $1951-1970$ & Schweikle et al. (1985) \\
\hline & Leipzig & 51.30 & 12.40 & 100 & 667 & 1961-1970 & Arranged from Hennings (2003) \\
\hline & Leipzig & 51.30 & 12.40 & 100 & 458 & 1971-1980 & Arranged from Hennings (2003) \\
\hline & Leipzig & 51.30 & 12.40 & 100 & 369 & 1981-1990 & Arranged from Hennings (2003) \\
\hline & Leipzig & 51.30 & 12.40 & 100 & 655 & $1991-2000$ & Arranged from Hennings (2003) \\
\hline & Leipzig & 51.30 & 12.40 & 100 & 771 & 2001-2010 & Arranged from Hennings (2003) \\
\hline & Mannheim & 49.50 & 8.50 & 97 & 710 & 1951-1980 & Schweikle et al. (1985) \\
\hline & München & 48.10 & 11.56 & 518 & 1394 & 1955-1974 & Rogler and Schwertmann (1981) \\
\hline & Villingen & 48.10 & 8.50 & 800 & 800 & 1951-1970 & Strauss et al. (1997) \\
\hline \multirow[t]{2}{*}{ Greece } & Patrai & 38.20 & 29.70 & 3 & 558 & $1961-1990$ & Arranged from Hrissanthou and Piliotis (1995) \\
\hline & Venetikos River & 40.09 & 21.15 & 900 & 812 & 1974-1983 & Panagoulia et al. (2004) \\
\hline \multirow[t]{5}{*}{ Hungary } & Gyöngyösoroszi & 47.80 & 19.90 & 881 & 853 & $1961-1990$ & Tamás and Kovács (2003) \\
\hline & Gyor & 47.70 & 17.70 & 129 & 670 & $1961-1980$ & Thyll (1992) \\
\hline & Nagykanizsa & 46.50 & 17.00 & 100 & 880 & 1961-1980 & Thyll (1992) \\
\hline & Sósi Creek River & 47.70 & 19.50 & 150 & 685 & 1961-1990 & Centeri et al. (2008) \\
\hline & Turkeve & 47.40 & 21.00 & 94 & 588 & 1961-1980 & Thyll (1992) \\
\hline \multirow[t]{7}{*}{ Italy } & Borgo S.Lorenzo & 41.46 & 12.90 & 12 & 1503 & $1998-2004$ & Diodato and Bellocchi (2010a) \\
\hline & Campochiaro & 41.50 & 14.52 & 502 & 1780 & 1994-2003 & Diodato and Bellocchi (2010a) \\
\hline & Carpeneto & 44.70 & 8.60 & 230 & 1432 & 1994-2003 & Diodato and Bellocchi (2010a) \\
\hline & Cesena & 44.00 & 12.20 & 44 & 1165 & 1951-1960 & Biagi et al. (1995) \\
\hline & Cesena & 44.00 & 12.20 & 44 & 1343 & 1961-1970 & Biagi et al. (1995) \\
\hline & Cesena & 44.00 & 12.20 & 44 & 1401 & 1971-1980 & Biagi et al. (1995) \\
\hline & Enna & 37.57 & 14.27 & 940 & 1324 & 1951-1993 & D'Asaro etal. (2007) \\
\hline
\end{tabular}


Appendix A (continued)

\begin{tabular}{|c|c|c|c|c|c|c|c|}
\hline Country & Station & $\begin{array}{l}\text { Latitude } \\
\text { (degree) }\end{array}$ & $\begin{array}{c}\text { Longitude } \\
\text { (degree) }\end{array}$ & $\begin{array}{c}\text { Elevation } \\
(\mathrm{m})\end{array}$ & $\begin{array}{l}\text { Actual rainfall- } \\
\text { runoff erosivity } \\
\left(\mathrm{MJ} \mathrm{mm} \mathrm{ha-1} \mathbf{h}^{-1} \mathbf{y}^{-1}\right)\end{array}$ & $\begin{array}{l}\text { Period } \\
\text { (years) }\end{array}$ & Sources \\
\hline & Monsampolo & 42.88 & 13.80 & 230 & 1300 & 1994-2003 & Diodato and Bellocchi (2010a) \\
\hline & Monteombraro & 44.40 & 11.20 & 727 & 1530 & 1956-1985 & Calzolari et al. (2001) \\
\hline & Palo del Colle & 41.00 & 16.70 & 177 & 808 & 1994-2003 & Diodato and Bellocchi (2010a) \\
\hline & Piano del Leone & 37.68 & 13.60 & 250 & 1073 & $1951-1970$ & D'Asaro et al. (2007) \\
\hline & Pontecagnano & 40.62 & 14.87 & 29 & 1478 & 1994-2003 & Diodato and Bellocchi (2010a) \\
\hline & Ramacca & 37.38 & 14.70 & 270 & 1589 & $1951-1970$ & D'Asaro et al. (2007) \\
\hline & Razzuolo & 44.00 & 11.50 & 650 & 2223 & $1981-2000$ & Borselli et al. (2004) \\
\hline & San Pietro & 37.57 & 15.00 & 330 & 1032 & 1995-2004 & Diodato and Bellocchi (2010a) \\
\hline & Sciacca & 37.50 & 13.08 & 60 & 674 & $1951-1970$ & D'Asaro et al. (2007) \\
\hline & Siracusa & 37.08 & 15.28 & 17 & 1054 & 1951-1970 & D'Asaro et al. (2007) \\
\hline & Volterra & 43.40 & 10.80 & 151 & 852 & 1964-1972 & Bazzoffi and Pellegrini (1991) \\
\hline & Volterra & 43.40 & 10.80 & 151 & 1034 & 1973-1981 & Bazzoffi and Pellegrini (1991) \\
\hline & Volterra & 43.40 & 10.80 & 151 & 1313 & $1982-1990$ & Bazzoffi and Pellegrini (1991) \\
\hline Morocco & Ain Boukellal & 34.16 & -4.12 & 500 & 957 & $1977-1994$ & Tribak et al. (2009) \\
\hline Netherlands & de Bilt & 52.00 & 5.13 & 5 & 799 & $1955-1974$ & Bergsma (1980) \\
\hline \multirow[t]{9}{*}{ Poland } & Elblag & 54.07 & 19.40 & 40 & 600 & $1960-1988$ & Baryla (2006) \\
\hline & Limanowa & 49.70 & 20.40 & 400 & 968 & $1960-1988$ & Banasik and Górski (2000) \\
\hline & Olszanka & 52.15 & 22.70 & 120 & 613 & $1951-1990$ & Olszty and Kowalskiego (2005) \\
\hline & Otwock & 52.10 & 21.40 & 100 & 580 & 1984-2002 & Arranged from Baryla (2004) \\
\hline & Puczniew & 51.78 & 19. 00 & 110 & 285 & 1983-1992 & Baryla (2006) \\
\hline & Puczniew & 51.78 & 19. 00 & 110 & 483 & 1993-2002 & Baryla (2006) \\
\hline & Sandomierz & 50.70 & 21.70 & 200 & 660 & $1960-1988$ & Banasik and Górski (2000) \\
\hline & Swinoujscie & 53.90 & 14.30 & 5 & 370 & 1961-1980 & Banasik and Górski (2000) \\
\hline & Suwalki & 54.00 & 22.90 & 170 & 426 & 1960-1988 & Banasik and Górski (2000) \\
\hline \multirow[t]{2}{*}{ Portugal } & Rio Leça (Porto) & 41.20 & -8.70 & 77 & 2993 & 1983-1994 & Petan et al. (2009) \\
\hline & Lagos & 37.08 & -8.67 & 35 & 1117 & 1971-1997 & $\begin{array}{l}\text { de Santos Loureiro and de Azevedo Couthino } \\
\text { (2001) }\end{array}$ \\
\hline \multirow[t]{2}{*}{ Romania } & Valea Calugareasca & 44.97 & 26.15 & 140 & 871 & $2002-2007$ & Cardei et al. (2009) \\
\hline & Zabala River & 45.88 & 26.18 & 600 & 913 & $1961-1990$ & Patriche et al. (2006) \\
\hline Serbia & Snagovo & 44.70 & 19.20 & 146 & 1391 & $1973-1990$ & Svetlana et al. (2006) \\
\hline \multirow[t]{2}{*}{ Slovakia } & Handlova & 48.73 & 18.75 & 420 & 630 & 1971-1990 & Šúri et al. (2002) \\
\hline & Oravska & 49.50 & 19.50 & 500 & 789 & $1971-1980$ & Maderková and Antal (2008) \\
\hline \multirow[t]{3}{*}{ Slovenia } & Solcava & 46.40 & 14.70 & 658 & 2258 & $1991-2010$ & Mikoš et al.(2006) \\
\hline & Murska Sobota & 46.70 & 16.10 & 190 & 1200 & 1991-2006 & Ceglar et al (2008) \\
\hline & Ratece & 46.50 & 13.70 & 900 & 1788 & $1991-2000$ & Ceglar et al (2008) \\
\hline \multirow[t]{15}{*}{ Spain } & Biescas & 42.63 & -0.32 & 875 & 2076 & 1971-1992 & Renschler et al. (1999) \\
\hline & Canelles & 42.00 & 0.30 & 700 & 1517 & 1937-1946 & Arranged from López-Vicente et al. (2007) \\
\hline & Canelles & 42.00 & 0.30 & 700 & 1043 & 1947-1956 & Arranged from López-Vicente et al. (2007) \\
\hline & Canelles & 42.00 & 0.30 & 700 & 1675 & 1967-1976 & Arranged from López-Vicente et al. (2007) \\
\hline & Canelles & 42.00 & 0.30 & 700 & 1034 & 1977-1986 & Arranged from López-Vicente et al. (2007) \\
\hline & Canelles & 42.00 & 0.30 & 700 & 1526 & 1987-1996 & Arranged from López-Vicente et al. (2007) \\
\hline & Canelles & 42.00 & 0.30 & 700 & 994 & 1997-2006 & López-Vicente et al (2007) \\
\hline & Conde Guadalhorce & 37.00 & -4.80 & 350 & 868 & 1965-1982 & Renschler et al. (1999) \\
\hline & La Molina & 42.40 & 2.00 & 1680 & 2172 & $1991-2000$ & Catari and Gallart (2010) \\
\hline & La Tejeria & 42.75 & -2.00 & 550 & 1000 & 1996-2005 & Casalì et al. (2008) \\
\hline & Montblanc & 41.38 & 1.16 & 400 & 1785 & 1992-2007 & Gazquez et al. (2002) \\
\hline & Real de San Vicente & 40.14 & -4.69 & 454 & 1450 & 1951-1970 & ICONA (1988) \\
\hline & Soutelo & 42.50 & -8.40 & 800 & 3020 & 1951-1970 & Fernandez et al. (2010) \\
\hline & Valencia & 39.47 & -0.37 & 15 & 1750 & 1983-2002 & Roldàn Soriano (2009) \\
\hline & Verin & 42.00 & -7.90 & 373 & 1000 & 1951-1970 & Fernandez et al. (2010) \\
\hline Switzerland & Frienisberg & 47.00 & 7.40 & 400 & 1200 & 1961-1990 & Arranged from Ledermann et al. (2010) \\
\hline Tunisia & Bargou & 36.00 & 9.50 & 600 & 680 & $1970-1994$ & Hamed et al. (2002) \\
\hline \multirow[t]{4}{*}{ Turkey } & Ankara & 39.95 & 32.85 & 100 & 692 & $1961-1990$ & Doğan (1987) \\
\hline & Istanbul & 41.00 & 29.10 & 799 & 740 & $1961-1990$ & Özhan et al. (2005) \\
\hline & Develi & 38.40 & 35.50 & 1173 & 632 & 1980-1999 & Irvem et al. (2007) \\
\hline & Goksun & 38.50 & 36.50 & 1180 & 1338 & 1980-1999 & Irvem et al. (2007) \\
\hline United Kingdom & Bala & 53.00 & -3.50 & 150 & 1200 & $1990-2000$ & $\begin{array}{l}\text { Arranged from Davison et al. (2005) and } \\
\text { Boardman (1993) }\end{array}$ \\
\hline
\end{tabular}




\section{References}

Alpert, P., Ben-Gai, T., Baharad, A., Benjamini, Y., Yekutieli, D., Colacino, M., Diodato, L. Ramis, C., Homar, V., Romero, R., Michaelides, S., Manes, A., 2002. The paradoxical increase of Mediterranean extreme daily rainfall in spite of decrease in total values. Geophysical Research Letters 29, 135-154.

Auerswald, K., Fiener, P., Dikau, R., 2009. Rates of sheet and rill erosion in Germany - a meta-analysis. Geomorphology 111, 182-193.

Barrera, A., Llasat, M.C., Barriendos, M., 2006. Estimation of extreme flash flood evolution in Barcelona County from 1351 to 2005. Natural Hazards and Earth System Sciences 6, 505-518.

Barroca, B., Bernardara, P., Mouchel, J.M., Hubert, G., 2006. Indicators for identification of urban flooding vulnerability. Natural Hazards and Earth System 6, 553-561.

Bintliff, J., 2002. Time, process and catastrophism in the study of Mediterranean alluvial history: a review. World Archaeology 33, 417-435.

Bocheva, L., Simeonov, P., Marinova, T., 2007. On frequency distribution and intensity of severe convective storms over Bulgaria. Proceedings of the Conference on Water Observation and Information System for Decision Support "BALWOIS 2006", Ohrid, Republic of Macedonia. A-100.

Brooks, H.E., Anderson, A.R., Riemann, K., Ebbers, I., Flachs, H., 2007. Climatological aspects of convective parameters from the NCAR/NCEP reanalysis. Atmospheric Research 83, 294-305.

Charlton, M., Fotheringham, S., 2009. Geographycally Weighted Regression (White Paper). National Centre for Geocomputation National University of Ireland, Maynooth. http://ncg.nuim.ie/ncg/GWR/GWR_WhitePaper.pdf.

Chirico, G.B., De Falco, M., Diodato, N., Romano, N., Santini, A., 2010. Valutazione dell'indice di erosività mensile da serie pluviometriche giornaliere. IDRA2010 - 32 Convegno Nazionale di Idraulica e Costruzioni Idrauliche, Palermo, Italy. \#C0190 (in Italian).

D'Odorico, P., Yoo, J., Over, T.M., 2001. An assessment of ENSO-induced patterns of rainfall erosivity in the Southwestern United States. Journal of Climate 14, 4230-4242.

Davison, P., Hutchins, M.G., Anthony, S.G., Betson, M., Johnson, M., Lord, E.I., 2005. The relationship between potentially erosive storm energy and daily rainfall quantity in England and Wales. The Science of the Total Environment 344, 15-25.

Diodato, N., 2004. Local models for rainstorm-induced hazard analysis on Mediterranean river-torrential geomorphological systems. Natural Hazards and Earth System 4, 389-397.

Diodato, N., 2006. Spatial uncertainty modeling of climate processes for extreme hydrogeomorphological events hazard monitoring. Journal of Environmental Engineering 132, 1530-1538.

Diodato, N., Bellocchi, G., 2007. Estimating monthly (R)USLE climate input in a Mediterranean region using limited data. Journal of Hydrology 345, 224-236.

Diodato, N., Bellocchi, G., 2009. Assessing and modelling changes in rainfall erosivity at different climate scales. Earth Surface Processes and Landforms 34, 969-980.

Diodato, N., Bellocchi, G., 2010a. MedREM, a rainfall erosivity model for the Mediterranean region. Journal of Hydrology 387, 119-127.

Diodato, N., Bellocchi, G., 2010b. Storminess and environmental changes in the Mediterranean Central Area. Earth Interactions 14, 1-16.

Diodato, N., Bellocchi, G., Romano, N., Chirico, G.B., 2011. How the aggressiveness of rainfalls in the Mediterranean lands is enhanced by climate change. Climatic Change 108, 591-599.

Durbin, J., Watson, G.S., 1950. Testing for serial correlation in least squares regression, I. Biometrika 37, 409-428.

Durbin, J., Watson, G.S., 1951. Testing for serial correlation in least squares regression, II. Biometrika 38, 159-179.

Easterling, D.R., Evans, J.L., Groisman, Ya, P., Karl, T.R., Kunkel, K.E., Ambenje, P., 2000 Observed variability and trends in extreme climate events: a brief review. Bulletin of the American Meteorological Society 81, 417-425.

Evrard, O., Nord, G., Cerdan, O., Souchère, V., Le Bissonnais, Y., Bonté, P., 2010. Modelling the impact of land use change and rainfall seasonality on sediment export from an agricultural catchment of the northwestern European loess belt. Agriculture, Ecosystems \& Environment 138, 83-94.

Foster, G.R., Meyer, L.D., Onstad, C.A., 1977. A runoff erosivity factor and variable slope length exponent for soil loss estimates. Transactions of ASAE 20, 683-687.

Fotheringham, A.S., Brunsdon, C., Charlton, M., 2002. Geographically Weighted Regression: The Analysis of Spatially Varying Relationships. John Wiley \& Sons, Hoboken.

Gaume, E., Bain, V., Bernardara, P., Newinger, O., Barbuc, M., Bateman, A., Blaškovičová, L. Blöschl, G., Borga, M., Dumitrescu, A., Daliakopoulos, I., Garcia, J., Irimescu, A., Kohnova, S., Koutroulis, A., Marchi, L., Matreata, S., Medina, V., Preciso, E., SempereTorres, D., Stancalie, G., Szolgay, J., Tsanis, J., Velasco, D., Viglione, A., 2009. A collation of data on European flash floods. Journal of Hydrology 367, 70-78.

Goldstein, H., 1987. Multilevel Models in Educational and Social Research. Oxford University Press, London.

Haylock, M.R., Goodess, C.M., 2004. Interannual variability of European extreme winter rainfall and links with mean large-scale circulation. International Journal of Climatology $24,759-776$

Grace, R.C., 2004. Temporal context in concurrent chains: I. Terminal-link duration. Journal of the Experimental Analysis of Behavior 81, 215-237.

Granger, C.W.J., Hyung, N., Jeon, Y., 2001. Spurious regressions with stationary series. Applied Economics 33, 899-904.

Guha-Sapir, D., Jakubicka, T., Vos, F., Phalkey, R., Marx, M., 2010. Health impacts of floods in Europe. Data gaps and information needs from a spatial perspective. A MICRODIS report. CRED School of Public Health, Catholic University of Louvain Brussels.
Hennings, V., 2003. Erosionsgefährdung ackerbaulich genutzter Böden durch Wasser (Karte im Maßstab 1:2,750,000). Nationalatlas Bundesrepublik Deutschland, Vol. 2: Relief, Boden und Wasser. Institut für Länderkunde [Hrsg.], Spektrum Akademischer Verlag, Heidelberg-Berlin, Germany.

Hrissanthou, V., 2005. Estimate of sediment yield in a basin without sediment data. Catena 64, 333-347.

James, P.M., 2007. An objective classification method for Hess and Brezowsky Grosswetterlagen over Europe. Theoretical and Applied Climatology 88, 17-42.

Johnston, K., 2004. ArcGis 9: using ArcGis Geostatistical Analyst. Esri Press, Redlands.

Kalnay, E., Kanamitsu, M., Kistler, R., Collins, W., Deaven, D., Gandin, L., Iredell, M., Saha, S., White, G., Woollen, J., Zhu, Y., Leetmaa, A., Reynolds, B., Chelliah, M., Ebisuzaki, W., Higgins, W., Janowiak, J., Mo, K.C., Ropelewski, C., Wang J., Jenne, R., Joseph, D., 1996. The NCEP/NCAR 40-year reanalysis project. Bulletin of the American Meteorological Society 77, 437-471.

Katz, R.W., Brown, B.G., 1992. Extreme events in a changing climate: variabilty is more important than averages. Climatic Change 21, 289-302.

Kenyon, J., Hegerl, G.C., 2010. Influence of models of climate variability on global precipitation extremes. Journal of Climate 23, 6248-6262.

Kottmeier, Ch., Kunz, M., 2002. Orographic Precipitation Enhancement during Extreme Flood Events in Mid-Europe. AGU Fall Meeting, San Francisco, CA, USA. (poster + abstract).

Liepert, B.G., Previdi, M., 2009. Do models and observations disagree on the rainfall response to global warming? Journal of Climate 22, 3156-3166.

Lionello, P., Bhend, J., Buzzi, A., Della-Marta, P.M., Krichak, S.O., Jansà, A., Maheras, P., Sanna., A., Trigo, I.F., Trigo, R., 2006. Cyclones in the Mediterranean region: climatology and effects on the environment. In: Lionello, P., Malanotte-Rizzoli, P. (Eds.), Mediterranean Climate Variability. Elsevier, Amsterdam, pp. 325-372.

Llasat, M.-C., Ceperuelo, M., Rigo, T., 2007. Rainfall regionalization on the basis of the precipitation convective features using a raingauge network and weather radar observations. Atmospheric Research 83, 415-426.

Llasat, M., Llasat-Botija, M., Prat, M., Porcú, F., Price, C., Mugnai, A., Lagouvardos, K., Kotroni, V., Katsanos, D., Michaelides, S., Yair, Y., Savvidou, K., Nicolaides, K., 2010. High impact floods and flash floods in Mediterranean countries: the FLASH preliminary database. Advances in Geosciences 23, 1-9.

Macklin, M.G., Benito, G., Gregory, K.J., Johnstone, E., Lewin, J., Michczyńska, D.J., Soja, R., Starkel, L., Thorndycraft, V.R., 2006. Past hydrological events reflected in the Holocene fluvial record of Europe. Catena 66, 145-154.

Mariotti, A., Ballabrera-Poy, J., Zeng, N., 2005. Tropical influence on Euro-Asian autumn rainfall variability. Climate Dynamics 24, 511-521.

Martí, P., Gasque, M., 2011. Improvement of temperature-based ANN models for solar radiation estimation through exogenous data assistance. Energy Conversion and Management 52, 990-1003.

Meusburger, K., Steel, A., Panagos, P., Montanarella, L., Alewell, C., 2011. Spatial and temporal variability of rainfall erosivity factor for Switzerland. Hydrology and Earth System Sciences Discussions 8, 8291-8314.

Mulligan, M., Wainwright, J., 2004. Modelling and model building. In: Wainwright, J., Mulligan, M. (Eds.), Environmental Modeling - Finding Simplicity in Complexity. John Wiley \& Sons, Chichester, pp. 7-73.

Nash, J.E., Sutcliffe, J.V., 1970. River flow forecasting through conceptual models. Part I - a discussion of principles. Journal of Hydrology 10, 282-290.

Nearing, M.A., Pruski, F.F., O'Neal, M.R., 2004. Expected climate change impacts on soil erosion rates: a review. Journal of Soil and Water Conservation 59, 43-50.

Papathoma, M., Dominey-Howes, D., 2003. Tsunami vulnerability assessment and its implications for coastal hazard analysis and disaster management planning, Gulf of Corinth, Greece. Natural Hazards and Earth System 3, 733-747.

Pekarova, P., Miklnek, P., Onderka, M., Halmova, D., Bacova Mitkova, V., Meszaros, I., Škoda, P., 2008. Flood regime of rivers in the Danube River Basin: a case study of the Danube at Bratislava. National report for the IHP UNESCO: Regional cooperation of Danube Countries within the framework of UNESCO International Hydrological Program, Bratislava.

Pelacani, S., Märker, M., Rodolfi, G., 2008. Simulation of soil erosion and deposition in a changing land use: a modelling approach to implement the support practice factor. Geomorphology 99, 329-340.

Poesen, J.W.A., Hooke, J.M., 1997. Erosion, flooding and channel management in Mediterranean environment of Southern Europe. Progress in Physical Geography 21, 157-199.

Previdi, M., 2010. Radiative feedbacks on global precipitation. Environmental Research Letters 5, 025211.

Previdi, M., Liepert, B.G., 2008. Interdecadal variability of rainfall on a warming planet. EOS. Transactions of the American Geophysical Union 89, 193-195.

Radziejewski, M., 2011. About trend detection in river floods. In: Kropp, J.P., Schellnhuber, H.J. (Eds.), In Extremis: Disruptive Events and Trends in Climate and Hydrology. Springer-Verlag, Berlin, pp. 145-165.

Renard, K.G., Foster, G.R., Weesies, G.A., McCool, D.K., Yoder, D.C., 1997. Predicting soil erosion by water: a guide to conservation planning with the Revised Universal Soil Loss Equation (RUSLE). USDA Agriculture Handbook, 703, pp. 27-28.

Romero, R., Miquel, G., Doswell III, C.A., 2007. European climatology of severe convective storm environmental parameters: a test for significant tornado events. Atmospheric Research 83, 389-404.

Rousseva, S., Stefanova, V., 2006. Assessment and mapping of soil erodibility and rainfall erosivity in Bulgaria. Proceedings of the Conference on Water Observation and Information System for Decision Support “BALWOIS 2006”, Ohrid, Republic of Macedonia. A-152.

Sánchez, J., Gallardo, E.C., Gaertner, M., Arribas, A., Castro, M., 2004. Future climate extreme events in the Mediterranean simulated by a regional climate model: a first approach. Global and Planetary Change 44, 163-180. 
Sauerborn, P., Klein, A., Botschek, J., Skowronek, A., 1999. Future rainfall erosivity derived from large-scale climate models - methods and scenarios for a humid region. Geoderma 93, 269-276.

Schaeffer, M., Selten, F.M., Opsteegh, J.D., 2005. Shifts of means are not a proxy for changes in extreme winter temperatures in climate projections. Climate Dynamics 25, 51-63.

Schär, C., Vidale, P., Luthi, D., Frei, C., Haberli, C., Liniger, M., Appenzeller, C., 2004. The role of increasing temperature variability for European summer heat waves. Nature 427, 332-336.

Schütt, B., Schwanghart, W., Ducke, K., Fritzenwenger, G., Hüsdler, J., Lange, J., Lippitz, A., Löwenhertz, R., Lubnina, T., Marquardt, N., Protze, N., Schimpf, S. Schobrabnski, F., 2007. Field study "Landscape sensitivity”. Landscape sensitivity in the Uguii Nuur catchment, Mongolia, with a special focus on soil erosion. Freie Universität Berlin, Berlin.

Twrdosz, R., 2007. Diurnal variation of precipitation frequency in the warm half of the year according to circulation types in Krakow, South Poland. Theoretical and Applied Climatology 89, 229-238.

Van Delden, A., 2001. The synoptic settino of thunderstorms in western Europe. Atmospheric Research 56, 89-110.

Van der Knijff, J.M., Jones, R.J.A., Montanarella, L., 2000. Soil Erosion Risk Assessment in Europe. EUR 19044 EN, European Soil Bureau, Space Application Institute, Joint Research Centre, Ispra.

Van Oldenborgh, G.J., Drijfhout, S., van Ulden, A., Haarsma, R., Sterl, A., Severijns, C., Hazeleger, W., Dijkstra, H., 2009. Western Europe is warming much faster than expected. Climology Past 5, 1-12.

Van Rompaey, A., Bazzoffi, P., Jones, R.J.A., Montanarella, L., 2005. Modeling sediment yields in Italian catchments. Geomorphology 65, 157-169.

Verheijen, F.G.A., Jones, R.J.A., Rickson, R.J., Smith, C.J., 2009. Tolerable versus actual soil erosion rates in Europe. Earth Science Reviews 94, 23-38.

Verstraeten, G., Poesen, J., Demarée, G., Salles, C., 2006. Long-term (105 years) variability in rain erosivity as derived from 10-min rainfall depth data for Ukkel (Brussels, Belgium): implications for assessing soil erosion rates. Journal of Geophysical Research 11, D22109.

Westra, S., 2011. Implications of Climate Change on Flood Estimation. UNSW Water Research Centre, The University of New South Wales, Sydney.

Wischmeier, W.H., Smith, D.D., 1978. Predicting rainfall erosion losses: a guide to conservation planning. Agriculture Handbook No. 537. USDA-SEA, US. Government Printing Office, Washington, DC.

Yang, D., Kanae, S., Oki, T., Koike, T., Musiake, K., 2003. Global potential soil erosion with reference to land use and climate change. Hydrological Processes 17, 2913-2928.

Zolina, O., Simmer, C., Belyaev, K., Kapala, A., Gulev, S., 2009. Improving estimates of heavy and extreme precipitation using daily records from European rain gauges. Journal of Hydrometeorology 10, 701-716.

\section{Further Reading}

Banasik, K., Górski, D., 2000. Estimating the rainfall erosivity for east and central Poland. Paper presented at 4th International Conference on Hydro-Science and Engineering, Seoul, South Korea.

Baryła, A., 2004. Erozyjność deszczy w rejonie Puczniewa - Przegląd Naukowy Inżynieria i Kształtowanie Środowiska. SGGW. z. 28: s. 279-283 (in Polish).

Baryla, A., 2006. Runoff volume and slope gradient relationship - laboratory investigations. Annals of Warsaw Agricultural University - SGGW Land Reclamation No 37, pp. 69-74.

Bazzoffi, P., Pellegrini, S., 1991. Caratteristiche delle piogge influenti sui processi erosivi nel periodo 1964-1990 in un ambiente della Valle dell'Era (Toscana). Evoluzione climatica e modelli previsionali: Annali Istituto Sperimentale per lo Studio e la Difesa del Suolo, 20, pp. 161-182 (in Italian).

Bergsma, E., 1980. Provisional rain-erosivity map of the Netherlands. In: De Boodt, M., Gabriels, D. (Eds.), Assessment of Erosion. John Wiley \& Sons, Chichester, pp. 121-126.

Biagi, B., Chisci, G., Filippi, N., Missere, D., Preti, D., 1995. Impatto dell'uso agricolo del suolo sul dissesto idrogeologico. Area pilota collina cesenate. Collana Studi e Ricerche, Regione Emilia Romagna, Assessorato Agricoltura, Bologna. (in Italian).

Boardman, J., 1993. The Sensitivity of Downland Arable Land to Erosion by Water. In: Thomas, D.S.G., Allison, R.J. (Eds.), John Wiley \& Sons, Chichester, pp. 211-228.

Bollinne, A., 1979. L'érosion en region limoneuse. Colloque sur l'érosion des sols en milieu tempéré. Strasbourg-Colmar, pp. 95-100 (in French).

Borselli, L., Cassi, P., Salvador Sanchis, P., Ungaro, F., 2004. Studio della dinamica delle aree sorgenti primarie di sedimento nell'area pilota del bacino di Bilancino. Progetto BABI, Rapporto finale. CNR-IRPI, Consiglio Nazionale delle Ricerche, Istituto di Ricerca per la Protezione Idrogeologica, Firenze (in Italian).

Calzolari, C., Bartolini, D., Borselli, L., Sanchiz, P.S., Torri, D., Ungaro, F., 2001. Caratterizzazione delle principali unità di suolo presenti nel territorio di collina in termini di rischio di erosione: la definizione del parametro $\mathrm{R}$, erosività delle piogge, per il modello RUSLE.C.N.R. IGES Technical Report 3.3. Regione Emilia Romagna, Servizio Cartografico and Geologico, Bologna (in Italian).

Cardei, P., Herea, V., Muraru, V., Sfiru, R., 2009. Vector representation for the soil erosion model USLE, a point of view. Bulletin of University of Agricultural Sciences and Veterinary Medicine Cluj-Napoca 66, 46-53.

Casalí, J., Gastesi, R., Álvarez-Mozos, J., De Santisteban, L.M., Valle, Del, de Lersundi, J., Giménez, R., Larrañaga, A., Goñi, M., Agirre, U., Campo, M.A., López, J.J., Donézar,
M., 2008. Runoff, erosion, and water quality of agricultural watersheds in central Navarre (Spain). Agricultural Water Management 95, 1111-1128.

Catari, G., Gallart, F., 2010. Rainfall erosivity in the upper Llobregat basin, SE Pyrenees Pirineos 165, 55-67.

Ceglar, A., Črepinšek, Z., Zupanc, V., Kajfež-Bogataj, L.A., 2008. Comparative study of rainfall erosivity for eastern and western Slovenia. Acta Agriculture Slovensky 91, 331-341.

Centeri, C, Vona, M. Penksza, K., Vona, V. 2008. Economic evaluation of nutrient loss through erosion on arable lands in the Sósi Creek watershed, Hungary. Lucrări Ştiintifice, Seria I X (1), 195-202 (in Hungarian).

D'Asaro, F., D'Agostino, L., Bagarello, V., 2007. Assessing changes in rainfall erosivity in Sicily during the twentieth century. Hydrological Processes 21, 2862-2871.

De Santos Loureiro, N., De Azevedo Couthino, M., 2001. A new procedure to estimate the RUSLE EI30 index based on monthly rainfall data applied to the Algarve region, Portugal. Journal of Hydrology 250, 12-18.

Doğan, O., 1987. Türkiye Yagıslarının Erosive Potansiyelleri. Tarım Orman ve Köyisleri Bakanlıgı, Ankara. (in Turkish).

Fernandez, S., Vega, J.A., Vieira, D.S., 2010. Assessing soil erosion after fire and rehabilitation treatments in NW Spain: performance of RUSLE and revised Morgan-Morgan-Finney models. Land Degradation and Development 21, 58-67.

Gazquez, A., Llsat, M.C., Pena, J.C., 2002. Gestión de las zonas agrícolas a partir de la red agrometeorológica de Catalunya (XAC). Estudio de la distribución de la agresividad de la lluvia. In: Guijarro Pastor, J.A., Grimalt Gelabert, M., Laita Ruiz de Asúa, M. Alonso Oroza, S. (Eds.), Publicaciones de la Asociación Española de Climatología (AEC), Serie A. Planográfica Balear, Marratxí (Mallorca), pp. 417-426 (in Spanish).

Hamed, Y., Albergel, J., Pépin, Y., Asseline, J., Nasri, S., Zante, P., Berndtsson, R., El-Niazy, M., Balah, M., 2002. Comparison between rainfall simulator erosion and observed reservoir sedimentation in an erosion-sensitive semiarid catchment. Catena 50 $1-16$.

Hrissanthou, V., Piliotis, A., 1995. Estimation of sediment inflow into a reservoir under construction. Proceedings of the 6th Conference of the Greek Hydrotechnical Union, Thessaloniki, Greece, pp. 355-362.

ICONA, 1988. Agresividad de la lluvia en España. Valores del factor R de la ecuación universal de pérdida de suelo. Ministerio de Agricultura, Pesca y Alimentación, Spain. (in Spanish).

Irvem, A., Topaloglu, F., Uygur, V., 2007. Estimating spatial distribution of soil loss over Seyhan River Basin in Turkey. Journal of Hydrology 336, 30-37.

Khentouche, A., 2005. Contribution à l'étude quantitative et qualitative de l'érosion dans le bassin versant de Oued Nafla (W. de Batna). PhD thesis, Faculty of Sciences, University of Batna, Algeria (in French).

Krasa, J., Dostal, T., Becvar, M., Vrana, K., 2005. Sediment transport in large watersheds in the Czech Republic. Geophysical Research Abstracts 7, Sref-ID:1607-7962/gra/ EGU05-A03626.

Krasa, J., Dostal, T., Vrana, K., 2007. Rain erosivity distribution in the Czech Republic. Geophysical Research Abstracts 9, 05270, SRef-ID:1607-7962/gra/EGU2007-A05270.

Ledermann, T., Herweg, K., Liniger, H.P., Schneider, F., Hurni, H., Prasuhn, V., 2010. Applying erosion damage mapping to assess and quantify off-site effects of soil erosion in Switzerland. Land Degradation and Development 21, 353-366.

López-Vicente, M., Navas, A., Machín, J., 2007. Identifying erosive periods by using RUSLE factors in mountain fields of the Central Spanish Pyrenees. Hydrology and Earth System Sciences Discussions 4, 2111-2142.

Maderková, L., Antal, J., 2008. Estimation the characterization of the erosive effective rainfall for the Slovak Republic. Report of Slovak Agriculture University in Nitra. Available at: http://www.ta3.sk/bioklima2009/Papers/Maderkova-Antal.pdf. accessed July 2011.

Mikoš, M., Jost, D., Petkovsek, G., 2006. Rainfall and runoff erosivity in the alpine climate of north Slovenia: a comparison of different estimation methods. Hydrological Sciences Journal 51, 115-126.

Olszty, W., Kowalskiego, D., 2005. Zintegrowany system zabezpieczeñ przeciwerozyjnych i ochrony wód terenów wyżynnych intensywnie użytkowanych rolniczo. Acta Agrophysica - Rozprawy i Monografie 121 (179) s., zał. (in Polish).

Özhan, S., Nihat Balci, A., Özyuvaci, N., Hizal, A., Gökbulak, F., Serengil, Y., 2005. Cover and management factors for the Universal Soil-Loss Equation for forest ecosystems in the Marmara region, Turkey. Forest Ecology and Management 214, 118-123.

Panagoulia, D., Zarris, D., Maggina, K., 2004. An assessment of the interaction between storm events and sediment transport. Proceedings of the 5th International Symposium on Ecohydraulics, vol. 1. Aquatic Habitats: Analysis \& Restoration, Madrid, pp. 281-286.

Patriche, C.V., Capatâna, V., Stoica, D.L., 2006. Aspects regarding soil erosion spatial modeling using the USLE/RUSLE within GIS. Geographia Technica 88, 87-97.

Petan, S., Taveira-Pinto, F., Miko, M., Pais-Barbosa, J., 2009. Modelação da erosão do solo da bacia hidrográfica do rio Leça, com a equação RUSLE e SIG. Recursos Hídricos 31 99-110 (in Portuguese).

Petković, S., Dragović, N., Marković, S., 1999. Erosion and sedimentation problems in Serbia. Hydrological Sciences Journal 44, 63-77.

Pihan, J., 1978. Risques climatiques d'érosion hydrique des sols en France. Colloque sur l'érosion agricole des sols en milieu tempéré non méditerran éen. Strasbourg/Colmar, niversité Louis Pasteur, INRA Colmar, pp. 13-18 (in French).

Renschler, C.S., Mannaerts, C., Diekkrueger, B., 1999. Evaluating spatial, temporal variability in soil erosion risk; rainfall erosivity, soil loss ratios in Andalusia, Spain. Catena 34, 209-225.

Rogler, H., Schwertmann, U., 1981. Erosivität der Niederschläge und Isoerodenkarte Bayerns. Zeitschrift für Kulturtechnik und Flurbereinigung 22, 99-112 (in German).

Rolànd Soriano, M. 2009. Estimación de la energía cinética de la lluvia a partir de la precipitación diaria. Nueva metodología para el cálculo del factor "R". Aplicación 
en España. $5^{\circ}$ Congreso Forestal Español. Ávila, España. Sept 21-25 Available at: http://www.ecogesfor.org/publicaciones.html. accessed July 2011.

Schweikle, V., Müller, M., Zuck, B., Pitsch, R., Dörr, D., Timmerberg, K., Buchleitner, Y., 1985 Regen- und Oberflächenabflußfaktoren $(\mathrm{R})$ sowie Bodenerodierbarkeitsfaktoren $(\mathrm{K})$ zur quantitativen Abschätzung des Bodenabtrags durch Wasser in Baden-Württemberg nach dem Verfahren von Wischmeier und Smith.- Anlage zum Bericht der LfU vom 11.11.85 (in German).

Strauss, P., Auerswald, K., Blum, W.E.H., Klaghofer, E., 1995. Erosivität von Niederschlägen. Ein Vergleich Österreich-Bayern. Zeitschrift für Kulturtechnik und Landentwicklung 36, 304-309 (in German).

Strauss, P., Paschen, A., Vogt, H., Blum, W.E.H., 1997. Evaluation of R-factors as exemplified by the Alsace region (France). Archives of Acker Pflanzenernahrung und Bodenkunde 42, 119-127.

Šúri, M., Cebecauer, T., Hofierka, J., Fulajtár, E., 2002. Soil erosion assessment of Slovakia at a regional scale using GIS. Ekológia (Bratislava) 21, 404-422.

Svetlana, B., Tomislav, S., Sonja, B., 2006. Definition of Rainfall Erosivity in the Area of the Experimental Station Snagovo. Proceedings of the Conference on Water Observation and Information System for Decision Support "BALWOIS 2006", Ohrid, Republic of Macedonia. A-183.
Tamás, J., Kovács, E., 2003. Evaluation of migration of heavy metal containing sediment resulting from water erosion using a geo-information model. Proceedings of the EFITA 2003 Information technology for a better agri-food sector, environment and rural living, Debrecen, Hungary, vol. 2, pp. 796-800.

Thyll, S., 1992. Talajvédelem és Vízrendezés Dombvidékeken. Mezőgazdasági Kiadó, Budapest. (in Hungarian).

Tribak, A., El Garouani, A., Abahrour, M., 2009. Évaluation quantitative de l'érosion hydrique sur les terrains marneux du PréRif oriental (Maroc): cas du sous-bassin de l'oued Tlata. Sécheresse 20, 333-337 (in French).

Ward, P.J., van Balen, R.T., Verstraeten, G., Renssen, H., Vandenberghe, J., 2009. The impact of land use and climate change on late Holocene and future suspended sediment yield of the Meuse catchment. Geomorphology 103, 389-400.

Wurbs, D., Steininger, M., 2011. Wirkungen der Klimaänderungen auf die Böden Untersuchungen zu Auswirkungen des Klimawandels auf die Bodenerosion durch Wasser Text Nr. 16/2011 UBA-FBNr: 001463 Förderkennzeichen: 370871 205. http://www.uba.de/uba-info-medien/4089.html. 